\title{
Cross-border media and nationalism:
}

\section{Evidence from Serbian radio in Croatia ${ }^{\perp}$}

\author{
Stefano DellaVigna, Ruben Enikolopov, Vera Mironova, Maria Petrova, Ekaterina \\ Zhuravskaya* $^{*}$
}

October 2012

\begin{abstract}
Which factors stand in the way of cooperation between countries formerly at war? We examine the role of nationalistic content of a media outlet reaching citizens of a neighboring country. We consider radio signals travelling across borders in the region that witnessed one of Europe's deadliest conflicts since WWII: the Serbo-Croatian conflict in the Yugoslavian wars. Using survey and election data, we show that, after a decade since the end of the war, cross-border nationalistic Serbian radio triggers animosity towards Serbs in Croatia, potentially endangering peace. In particular, we find that a large fraction of Croats listen to Serbian radio (intended for Serbian listeners across the border) whenever signal is available. The residents of Croatian villages with good-quality signal of Serbian public radio are more likely to vote for extreme nationalist parties. In addition, ethnically offensive graffiti are more common in villages with Serbian radio reception. A laboratory experiment confirms that Serbian radio exposure causes an increase in anti-Serbian sentiment among Croats.
\end{abstract}

\footnotetext{
${ }^{\perp}$ Our special thanks go to Kristina Gulmac, Tihomir Zivic and to the University of Vukovar for the invaluable help with the organization of the lab experiment. We are very grateful to Ben Olken for providing the software necessary for ITM calculation. We also thank Bulat Gafarov, Roman Istomin, Blazo Kazanegra, Andrey Korolev, and Gleb Romanyuk for excellent research assistance. We thank Matthew Gentzkow, Irena Grosfeld, Ethan Kaplan, Fernanda Leite Lopez de Leon, John Londregan, Tom Romer, John Schiemann, David Strömberg, and audiences at Columbia, Harvard, IIES at the University of Stockholm, IMT Lucca, Princeton, Zurich, Paris School of Economics, the $8^{\text {th }}$ Workshop on Media Economics, NBER Summer Institute in Political Economics, University of Maryland, and Hebrew Univestiy for useful comments.

* Stefano DellaVigna is from the Department of Economics at the University of California, Berkeley. Ruben Enikolopov and Maria Petrova are from the New Economic School, Moscow. Vera Mironova is from the Department of Government and Politics, University of Maryland. Ekaterina Zhuravskaya is from Paris School of Economics (EHESS) and the New Economic School.

Corresponding author: Maria Petrova, New Economic School, Office 1721, Nakhimovsky pr. 47, Moscow Russia.E-mail: mpetrova@nes.ru.
} 


\section{Introduction}

What fuels hostility and conflict between neighboring countries? Which factors stand in the way of a durable peace and cooperation between countries that were formerly at war? A substantial literature has considered the importance of differences in income and resources, political institutions, aid, and the history of relationships between ethnic groups, among other factors, as reviewed in Blattman and Miguel (2010) and Jackson and Morelli (2011).

In this paper, we consider the impact of an understudied factor: cross-border media exposure. Oftentimes, neighboring countries share a language or a language group. This is particularly likely for countries that formerly belonged to one larger entity, such as the U.S.S.R, Yugoslavia, or more recently Sudan. Citizens of these countries, and especially those who live close to the border, are exposed to the media of their neighbors because radio and television waves travel across political boundaries. The exposure to cross-border media can be particularly important when the media outlets have nationalistic content, for example for nation-building purposes, and when the two nations have a history of conflict.

Is exposure to cross-border nationalistic media likely to trigger nationalism among neighboring population? An increase in nationalism would then increase the chance of future conflict. The effect of exposure to nationalistic content of cross-border media is not a priori obvious. On the one hand, it may trigger nationalistic sentiment among the neighboring population, increasing polarization of political views, and thus making future conflict more likely. An alternate possibility is that such exposure may instead reduce informational asymmetries and alleviate ethnic tensions (Allport 1954). Finally, the cross-border impact of media may be negligible, particularly if people mostly listen to media outlets that support their own views (Sunstein, 2001; Durante and Knight, forthcoming).

This paper examines the impact of cross-border media exposure on nationalistic behavior in the aftermath of one of Europe's deadliest conflicts since WWII, namely, the Serbo-Croatian conflict in the 1991-95 Yugoslavian wars. The region of Croatia near the Serbian-Croatian border was the site of a full-scale armed conflict between Serbs and Croats in 1991 and was under Serbian occupation till 1995. The military operations of the Serbian-Croatian conflict ended in 1995 and Slobodan Milošević - the former president of Serbia-was overthrown in 2000 and handed to the Hague International Criminal Tribunal. Still, in the following decade the public media in Serbia has continued to promote Serbian nationalism. In particular, public radio stations (i.e., radios of the Radio-Television of Serbia group, RTS, also known as Serbian Broadcasting Corporation) operate with the official mission to strengthen Serbian national identity (IREX 2010). This raises the question of the impact of the Serbian nationalistic radio on nationalistic sentiment in Croatia, which we address in this paper.

The Serb-Croat case is a nearly ideal setting to study cross-border effects of media. The signal of Serbian public radio intended for internal consumption inside Serbia reaches several, but not all, villages in this region of Croatia. As Serbs and Croats speak the same language, 
despite using different alphabets, Croats can fully understand Serbian radio. ${ }^{1}$ We are able to narrow down the analysis of cross-border effects of media exposure to radio content because radio is the primary media source in this area.

We use detailed village-level information on media reception, voting, and other nationalistic behavior to answer two key questions: Do Croats actually listen to Serbian radio when it is available? If so, does Serbian radio have any effect on nationalistic political views and attitudes towards Serbs?

Using a street survey of residents of Croatian villages located close to the Serbian border, we find that the answer to the first question is positive. In areas where Serbian radio signal is available without any special amplifiers, $87 \%$ of respondents are aware of getting the signal; whereas in areas where a special amplifier is needed to get reception, $56 \%$ of respondents report having access to Serbian radio. Among those who responded positively to the question whether they get Serbian radio, $78 \%$ of respondents acknowledge that they listen to Serbian radio occasionally, and one half admits to listening to Serbian radio at least several times a month. The high percentage of listeners of Serbian radio among Croats stands in contrast with an extreme view of political polarization -- that consumers only listen to media outlets that conform to their political beliefs -- and is consistent with more moderate evidence of polarization in the US media (Gentzkow and Shapiro, 2011). ${ }^{2}$

Does Serbian radio then trigger nationalistic views and behavior among Croats? We estimate the effect of Serbian radio on the propensity to vote for extremist nationalist parties and other political parties, as well as expressions of ethnic hatred, namely anti-Serbian graffiti. Our identification strategy relies on variation in the availability of Serbian radio among different villages in the border region.

We use two measures of availability of Serbian radio. As the first measure, we use handcollected data on actual availability of Serbian (RTS) radios in 139 villages in the region adjacent to Serbian border (our baseline sample), measured using an ordinary receiver. As the second measure, we compute signal strength of Serbian radios using information on Serbian transmitters and the topography of the region for all 417 villages in Croatia within 75 kilometers of the Croatian-Serbian border (our extended sample). The two measures, which are positively correlated, are complementary: the hand-collected measure captures fine variation in radio reception which the signal strength calculations do not, but is affected by unavoidable errors in hand measurement; the signal strength is available for a larger sample.

In both the baseline and extended sample, the availability of Serbian (RTS) radio significantly increased the votes for extremist nationalist political parties during the most recent Parliamentary election in 2007. The effect is larger where the reception of the radio signal is

\footnotetext{
1 According to Greenberg (2004), the difference between Serbian and Croatian spoken language is similar in magnitude to the difference between British and American English.

2 Anecdotal evidence from the authors' interviews with Croatian media experts suggests, in addition to a desire for alternative information, Croats tune in to Serbian radio to listen to Serbian singers from the times of Socialist Yugoslavia, and in doing so encounter also political content.
} 
stronger and holds using both measures of radio availability. The estimates imply that a substantial part of the vote for ultra-nationalist parties in the border region of Croatia is explained by the reception of Serbian radio.

As the measures of availability of Serbian radio may correlate with other determinants of nationalistic voting and this correlation could generate spurious results, we document what determines the variation in radio availability. The hand-collected radio reception measure is orthogonal to a large set of observables, including distance from the border, measures of exposure to the war and of the presence of Serbian minority. This result is consistent with the variation in reception being reasonably idiosyncratic. The second measure is correlated with distance from the border and the village population. We show that adding extra geographic and demographic controls to the specification estimating the effect of signal strength leaves the estimates unaffected or makes them larger. As the size and direction of potential bias due to omitted confounds depends on their effect on nationalistic voting, we use an index variable for the controls to show that the observables are negatively related (though insignificantly so) to nationalistic voting. This is true for all groups of control variables. This test, in the spirit of the Altonji-Elder-Taber (2005), suggests that, to the extent that the unobservables are positively correlated with the observables, the estimates of the impact of radio on nationalism are likely to be biased downward.

In addition, as a quasi-placebo experiment, we examine the impact of the reception of other radios that are not expected to influence nationalistic feelings. In particular, we show that cross-border exposure to Hungarian radio, which broadcasts in a language understood by very few Croats, does not have any impact. We also find no evidence that villages with exposure to two popular Croatian radios vote more for nationalistic parties. Hence, the effect of exposure to Serbian radio is unlikely to be due to geographic features associated in general with both more nationalism and better radio signal reception.

We also consider a number of specification checks to assess the robustness of the results and to address alternative explanations. The results are not affected by a correction for spatial correlation, by alternative measures of the vote share for the nationalistic party, or by the use of a matching estimator instead of OLS. Controlling for additional measures of distance from the border (i.e., driving time or distance) and for war experience (proximity to war events during the Serbo-Croatian conflict) does not affect the results either, suggesting that proximity to the former enemy or past war experience are not driving the results. Finally, additional controls for the signal strength of two major Croatian radios do not eliminate the impact of Serbian radio, suggesting that substitution away from Croatian radio is unlikely to be the main channel of the results.

To quantify the media effect, we combine the voting results and the street survey results to compute a persuasion rate, i.e., the fraction of Croats who changed their voting behavior in response to Serbian radio among those who were exposed (DellaVigna and Kaplan 2007; DellaVigna and Gentzkow 2010). The implied persuasion rate of $3 \%$ to $4 \%$ is on the lower end 
of the estimates of persuasion rates of media on their intended recipients. The computations of average treatments on the treated yield comparable effect sizes.

We consider the impact of Serbian radio on other political outcomes as well. We find that the exposure to Serbian radio reduces the vote share for the moderate nationalistic party and in some specifications increases the vote share for the social-democratic party, suggesting an increased polarization of the electorate.

As a measure of non-political expression of nationalistic sentiment, we consider the presence of graffiti offensive to Serbs in the open spaces in the village. We find that Serbian radio availability is associated with a significantly higher likelihood of having ethnicallyoffensive graffiti in the village center Hence, the impact of radio exposure on nationalistic feelings extends beyond political choices.

To provide further evidence on the impact of radio exposure, we conducted a laboratory experiment. Eighty ethnic Croatian students of Vukovar University listened to different remixes of radio broadcasts and were then questioned on their attitudes towards different ethnic groups and political parties. Students were randomly allocated into three groups: the control group listened to a remix of Croatian radios; the first treatment group listened to a remix of Croatian radios and Serbian public (RTS) radios; and the second treatment group listened to a remix of Croatian and Serbian private radio (B92), which has a more neutral attitude towards Croats. Compared to the control group, the two groups exposed to Serbian radio display significantly heightened animosity towards Serbs in attitude questions, and the increase is larger for the group exposed to RTS radio. As predicted, neither of the treatments changed subjects' attitude towards other ethnic groups, i.e., Bosnians or Hungarians. Exposure to Serbian radio increased (though not significantly so) the self-reported preference for extremely nationalistic parties, though with a different pattern of substitution for other parties compared to the field evidence.

Since subjects treated with Serbian nationalistic public radio, openly hostile to Croats, were more affected by the experiment than those treated with a more neutral Serbian radio, we conclude that most of the estimated effect of Serbian public radio comes from reminding Croats specifically about concurrent Serbian nationalism and anti-Croatian rhetoric rather than reminding them that their former enemy is just across the border.

Overall, our results suggest that Serbian public radio hostile to Croats appears to have an important effect working across the border resulting in a substantial increase in extremist nationalistic sentiment among Croatian population, potentially endangering the continuation of peaceful relations between the two countries.

Our paper is related to the literature on the effect of media on political outcomes (e.g., Strömberg 2004; Gentzkow 2006; DellaVigna and Kaplan 2007; Gerber, Karlan, and Bergan 2009; Snyder and Strömberg 2010; Knight and Chiang 2011). While most of this literature studies developed countries, we contribute to the smaller but growing strand of the literature providing evidence outside the developed world (e.g., Lawson and McCann 2005; Olken 2009; and Enikolopov, Petrova, and Zhuravskaya 2011). In contrast to the previous literature, which 
largely focused on on-target audiences, we identify what is likely to be an unintended media effect on an off-target audience in a conflict environment. While we cannot completely rule out the possibility that the Serbian radios have the intent to trigger animosity among Croats, it is unlikely since the vast majority of listeners to these radios are Serbs in Serbia. If these radios were targeted at Croats, the transmitters would have been placed closer to the Croatian border to increase the penetration into the Croatian territory.

Within the media literature, the paper is related to work examining the effect of media on ethnic conflict. For instance, Yanagizawa (2009) uses variation in radio coverage to investigate the effect of "hate speech" on casualties from the genocide in Rwanda in 1994. Gentzkow and Shapiro (2004) argue that media in Arabic countries biased against the US reinforces antiAmerican sentiment in the population. While these papers measure the effects of propaganda in fueling ethnic animosity on the intended audiences, we examine the unintended media effect as a catalyst of ethnic hatred. In contrast to these papers, our analysis also includes complementary evidence from a survey of individuals and a laboratory experiment. Our findings are also related to the papers on cross-border effects of the media. Hainmueller and Kern (2009) and Bursztyn and Cantoni (2011) examine how the availability of free West German TV affected the behavior of residents in the German Democratic Republic. Butler and De La O (2011) study how the availability of foreign TV affects the interest of Swiss in their own domestic elections. Unlike in these papers, our focus is on ethnic tensions and nationalism.

Our paper is related to the vast literature on the determinants of conflict (see, for instance, Dube and Vargas 2011, Caselli et al. 2012, Hess and Orphanides 1995, Jackson and Morelli 2007, Dube and Naidu 2012, Esteban and Ray, 2008, Chassang and Padró i Miquel 2010, Jha 2008, Voigtländer and Voth 2012). Our paper is the first one to consider cross-border media as a potential catalyst of conflict. We contribute to the literature on attitudes in post-conflict societies (e.g., Acemoglu and Wolitsky 2012, Rohner et al. 2012, Bellows and Miguel 2009, Blattman 2009, and Voors et al. 2012). Our experimental evidence suggests that exposure to media of a former enemy is likely to increase tensions and nationalism.

Our paper is also related to the literatures in economics and social psychology, starting with the seminal work of Allport (1954), on the effect of the exposure to representatives of different ethnic and religious groups on conflict and inter-group animosity. Depending on particular circumstances, inter-ethnic and inter-religious mixing was found to reinforce and to weaken ethnic tensions (see, for instance, Dovidio et al. 2005, Pettigrew and Tropp 2006, Van Laar et al. 2005, Boisjoly et al. 2006, and Barnhardt 2009). We document a negative exposure effect, suggesting that increased exposure of Croats to Serbians news is unlikely, at least for now, to improve relations.

The rest of the paper is organized as follows. Section 2 provides background information on the conflict and the mass media in the former Yugoslavia and elections in Croatia. Section 3 presents our hypotheses and describes the data on outcomes. Section 4 explains the variation in Serbian radio signal in Croatia. Section 5 presents the empirical results. Section 6 presents the 
results of the laboratory experiment and Section 7 concludes.

\section{Background}

Conflict. The Croatian-Serbian conflict (1991-1995) was one of several major openarmed conflicts in the former Socialist Yugoslavia, known as Yugoslavian wars. Croatians are predominantly Catholic Christians, whereas Serbians are predominantly Orthodox Christians. Ethnic animosity between the two groups goes back at least to the beginning of the $20^{\text {th }}$ century and had been escalating since the 1980s. The armed conflict started in 1991. The Croatian side aimed at establishing a sovereign state independent of Yugoslavia, while the Serbian minority, which quickly got military support from Serbia, opposed the secession and wanted Croatia to remain a part of Yugoslavia (with the center in Belgrade, Serbian capital city). Subsequently there was a series of deadly military operations, which included massacres of civilians and ethnic cleansing on both sides. The conflict ended in 1995 with Croatia achieving the goal of becoming an independent country within the borders that it claimed in 1991. Estimates of the number of victims for the Croatian-Serbian conflict alone amount to roughly 250,000 displaced civilians and 20,000 casualties (the vast majority of which were civilians). ${ }^{3}$ Some episodes of the Yugoslavian wars were formally characterized as genocide. To investigate and prosecute Yugoslavian war crimes, the UN established the International Criminal Tribunal.

The mass media played a crucial role in fueling ethnic animosity and escalating the conflict before and during disintegration of Socialist Yugoslavia (see, for instance, Thompson 1994; Skiljan, 2000, and Hockenos 2003). In particular, Smajlović (1997), Kurspahić (2003), and MacDonald and Bruce (2002) present evidence that media outlets that belonged to the RTS media group, including Serbian public radio, were engaged in active pro-Serbian and antiCroatian propaganda during the conflict. They actively supported the Milošević regime, denied Serbian aggression, and selectively covered information on victims of war from the Serbian side. Smajlović (1997) reports results of surveys, which show that most of the Serbian population trusted RTS news during the conflict.

Media. There are four major types of media today in the region of our study: Croatian television, Croatian print media, Croatian radio, and Serbian radio. Croats in this region do not typically consume either Serbian print media or Serbian television. While it is easy for them to listen to Serbian radio, as they speak the same Serbo-Croatian language, it is more difficult for them to read most of the Serbian newspapers, as Serbs use Cyrillic alphabet more often then Latin, whereas Croats use exclusively Latin alphabet. Watching Serbian television is similarly difficult as it often includes foreign programs that use Cyrillic subtitles.

Of the four prominent media, Croatian television and print media play smaller roles relative to the radio in our region. In many areas, people do not possess television sets, but do own radio receivers. While we do not have data on TV and radio set ownership specifically for

\footnotetext{
3 "Presidents apologise over Croatian war". BBC News Online. BBC. September 10, 2003. http://news.bbc.co.uk/2/hi/europe/3095774.stm
} 
our region, in the whole country the number of TV sets was 281 per 1000 inhabitants and the number of radios was 336 per 1000 inhabitants in 2003. In the rural areas, which are the focus of the study, the imbalance in favor of radio receivers is likely larger. In addition, Croatian law requires that all legally owned television sets be registered with a paid subscription to Croatian television channels. The price of monthly subscription is high by local standards (starting at $10 €$ per month), so typically residents in rural areas do not register their TV sets; without paid subscription, the quality of the TV signal is poor. ${ }^{4}$ Regarding newspapers, few people in rural areas purchase print media, and, indeed, in some villages there is no place to buy a newspaper.

Given the constraints outlined above, radio has been the most important source of information about politics since the times of Socialist Yugoslavia. A typical Croatian listens to radio for approximately 250 minutes a day (Peruško and Jurlin 2006). Most people in the region do not turn off the radio during the day, and many listen to it on the streets.

The radio market in Croatia is localized, with 3 national public channels having a joint share of just $10 \%$ of radio audiences. This stands in contrast to the high concentration and state ownership in television and newspaper markets. Local radio stations in Croatia are controlled by local governments who own $70 \%$ of the local media and also indirectly control the remaining stations. Nearly half of the local radio stations are financially dependent on support from local authorities (Peruško and Jurlin 2006).

Parliamentary elections and parties in Croatia. The Croatian Parliament (Sabor) has one chamber with members elected every four years. There are 10 multi-member electoral districts in mainland Croatia and an additional electoral district giving representation to Croatians living abroad. The electoral rule in each district is proportional representation with closed party lists and the minimum of $5 \%$ of total vote to get representation, with 8 seats reserved for ethnic minorities. At the time this paper was written, the last parliamentary election took place in November 2007. This was the third post-war parliamentary election and the first one taking place in a relatively stable economic and political environment. In total, 145 representatives were elected from 11 districts representing 8 parties (and party alliances).

The two main political parties in Croatia (HDZ and SDP) have very different views on the issue of nationalism. The political party which got the largest share of the total vote $(36.6 \%)$ and most seats (66) in 2007 is the Croatian Democratic Union (HDZ, Hrvatska demokratska zajednica). It is the main center-right political party with a moderate nationalist pro-Croatian ideology. It was founded by nationalist dissidents in 1989 and led by Franjo Tudjman, the first president of Croatia. The party entered parliament in 1990 and positioned itself as antiCommunist and anti-Serbian-nationalism of Slobodan Milošević. During the war of independence, HDZ was in power and many members of the military were also members of the party. One of the new proclaimed goals of HDZ in the 2000s was the accession of Croatia into the EU, which moved the party substantially towards the center.

The second largest political party in Croatia (with 56 seats and $31.2 \%$ of total vote in

\footnotetext{
${ }^{4}$ Source: authors' interview with Ivana Cosic, the adviser of Croatian Ministry of Education, Science and Sport.
} 
2007) is the Social Democratic Party of Croatia (SDP, Socijaldemokratska partija Hrvatske). This center-left opposition party is usually considered as the heir of the Communist Party of Croatia. Among all major political parties, SDP has the most neutral position vis-à-vis Serbia, and it is the most popular party among the Serbian minority in Croatia.

The remaining 23 seats of the 2007 Sabor are shared among 6 political parties, which have a substantially smaller political base in the entire country, but a few of them have significant political support in some parts of the country. In particular, the ultra-nationalist political party, the Croatian Party of Rights (HSP, Hrvatska stranka prava), is fairly popular in the border region with Serbia, which is the focus of our study. It got $8 \%$ of the total vote in the northern part of the border region and 5.2\% in the southern part; as a result, it gained one seat in the Croatian parliament of 2007. This party is the main extreme nationalist party in Croatia (Laqueur 1997, Hislope 1996) with the ideology of supporting "the Great Croatia." ${ }^{5}$ In the 1990s, HSP created its own paramilitary unit that aimed to secure Croatian independence from Yugoslavia (UNCE 1994) and used the symbols resembling those of the fascist state during the WWII. ${ }^{6}$ After the war, two wings of HSP seceded because of internal party conflicts and formed independent political parties (HP-HPP and HCSP). These parties are very small, but they share the same ultra-nationalist ideology and find some (insignificant) support in the border region. ${ }^{7}$

The other political parties that got representation are as follows: two regionally-oriented parties (Istrian Democratic Assembly, IDS, and Croatian Democratic Alliance of Slavonija and Baranja, HDSSB); a party with liberal ideology (HNS-LD); a single-issue pensioners party (HSU) and an agrarian socialist party (HSS - HSLS).

For the purposes of our study, we characterize the main Croatian political parties according to the strength of their nationalistic rhetoric in 2007-2010. We consider HSP together with its former factions (HP-HPP and HCSP) as extreme nationalistic; HDZ as moderately nationalistic; and SDP as neutral. ${ }^{8}$

Region. Our main focus is on the border region of Croatia, Eastern Slavonia, Baranja and Western Srijem (Figure 1a). The region consists of two counties, which differ in terms of local politics. The first county, Vukovar-Sirmium, suffered the most during the war in terms of

\footnotetext{
5"Velika Hrvatska," or Great Croatia, is the ideology of modern Croatian ultra-nationalists, according to which Croatia should be only for Croats and its territory should unite all the lands that belonged to Croatia before Ottoman invasions of the 15th, 16th and 17th century. These territories include parts of modern Serbia, Bosnia and Herzegovina, and Montenegro (Vienna Profit, August 31992 in FBIS Daily Report (Eastern Europe), August 3, 1992. pp, 26-7).

${ }^{6}$ For example, HSP uses the symbols of the former Ustaše movement such as the letter "U" on the uniforms of its military wing. Ustaše was the Croatian Nazi movement in power during WWII. The war-time leader Dobroslav Paraga used to end his speeches with a Nazi salute (Hislope 1996).

7 Despite our focus is on relatively small parties, one should not underestimate their potential impact on policy. See, for instance, Folke (2011), who shows that marginal political representation of small parties had a large effect on environmental and immigration policies of Swedish municipalities.

8 One of the regional political party, Croatian Democratic Alliance of Slavonija and Baranja (HDSSB, Hrvatski demokratski savez Slavonije i Baranje) may also be considered as moderately nationalistic as its leader, Branimir Glavaš, was one of the main defenders of the city of Osijek during the war. However, its main goals are in development of Osijek region and securing central budget transfers for it. The results are robust to characterising HDSSB as moderately nationalistic in addition to HDZ, the main party of power.
} 
the number of casualities and physical damage. For a substantial period during the conflict-at the time of the Republic of Serbian Krajina, a self-proclaimed Serbian entity inside Croatia—all Croats in this part of the region were displaced or killed. As a result, Croats living in this area are substantially more nationalistic than the national average.

The second county, Osijek-Baranja, includes two subregions, Osijek and Baranja. Nationalistic sentiments are also important in Osijek, but are less wide-spread than in Western Srijem and Eastern Slavonia. This subregion is the stronghold of HDSSB (Croatian Democratic Alliance of Slavonija and Baranja regional party). Unlike the rest of the border region, Baranja has a significant Hungarian minority (close to $20 \%)^{9}$ and, as a consequence, the population of Baranja shows relatively low support for Croatian nationalistic ideas. During the war, Baranja was occupied by Serbs almost without resistance. In the empirical analysis, we include county fixed effects and thus focus on the within-county variation.

\section{Hypotheses and the data}

Hypotheses. We test whether exposure to Serbian public radio triggers nationalistic antiSerbian feelings among Croats. There could be several potential belief-based mechanisms underlying this hypothesis. First, Serbian radio may increase Croats' awareness of Serbian nationalism in the past and remind them about the war (Zaller 1992). Second, listening to Serbian radio might increase the perceived probability among Croats of new war with Serbia in the future. Finally, Croats may believe that Serbian radio affects Serbs still living in Croatia, which, in turn, may increase the probability of a new civil war in Croatia.

The main testable implication is that Croats exposed to Serbian radio are more likely to vote for Croatian extreme nationalist parties (i.e., HSP and its former factions, HCSP and HPHPP). The literature on ultra-right party voting shows that fear is an important determinant of such behavior (Jackman and Volpert 1996, Voerman and Lucardie 1992).

Which groups of voters are expected to move to the extreme nationalistic right as a result of Serbian radio exposure? There are two possibilities: those who abstain in the absence of Serbian radio and those who vote for less extreme parties. As it is easier to move to the ultra right from the moderate right rather than from any left-wing position on the scale of nationalistic political preference, we expect to see fewer people voting for the moderate nationalist party (HDZ) than for the neutral-toward-Serbs Social Democratic Party (SDP) as a result of Serbian radio exposure. The prediction about the effect of Serbian radio on Croatian turnout is ambiguous. On the one hand, it could increase due to a mobilization effect (as in DellaVigna and Kaplan 2007). On the other hand, it could decrease as people can get distracted from local policy issues (as in Snyder and Strömberg 2010).

Furthermore, anti-Serbian feelings among Croats can be expressed in various ways other than voting for extreme-nationalistic parties. We test whether the likelihood of ethnicallyoffensive graffiti displayed on the walls of public buildings on the central streets of Croatian

\footnotetext{
${ }^{9}$ Croatian Census 2001. http://www.dzs.hr/Hrv/censuses/Census2001/Popis/H01_02_02/H01_02_02_zup14.html
} 
villages is higher in areas where Serbian public radio is available.

Electoral measures. We use data from the 2007, the most recent election to the Croatian parliament. We obtained the results at the level of polling stations from the Central Election Commission of Croatia. We match and aggregate these data to the village-level. The vast majority of villages include 1 to 4 polling stations, though some villages have more polling stations and some polling places cover several (typically small) villages.

As we describe in the background section, we construct vote share measures for extreme nationalist parties (HSP, HP-HPP and HCSP), for moderate nationalist parties (HDZ), and for parties without nationalistic ideology (SDP). Turnout is measured as the total votes cast divided by the number of eligible voters.

Ethnically-offensive graffiti. We visited all the villages in the main sample (described below) and collected information about the presence of ethnically-offensive graffiti on public buildings in the centers of villages. We classified graffiti as being ethnically offensive according to the methodology used by local NGO Globalpact in Vukovar in 2008. Representative examples of these graffiti are slogans as "Ubi Srbina" ("Kill a Serb") or "Srbe na vrbe" ("Hang a Serb on a willow") (Figure 5 presents an example). We generate an indicator variable for villages with graffiti which are "somewhat" or "strongly offensive" towards Serbs. Of the 139 villages we visited, 36 had ethnically-offensive graffiti.

Control variables. Demographic control variables come from the most recent Croatian Census of $2001 .{ }^{10}$ We use the village level variables: logarithm of population, share of males, fractions of people between 21 and 40, between 41 and 60, and over 60 years of age. We also include controls at the level of municipality (općina), which typically includes several villages: labor force participation, share of population disabled after the War of independence, the shares of Croats, and the share of people with higher education.

We collected additional variables during our visits to the villages in 2009 and 2010: (i) the language in which the street names are written -indicators for Cyrillic script and for Hungarian language and (ii) an indicator for signs that advertised Serbian beer outside village bars, since people of Serbian, but not Croatian, origin prefer beer produced in Serbia (e.g., Jelen pivo); (iii) an indicator for official monuments in the honor of the Croatian defenders killed during the Serbo-Croatian war; (iv) an indicator for whether the village played an important role during the war, as coded by a former military official in charge of defending this region. The last two measures can also serve as proxies for war background of a village.

To control for geographic location, we use the log of minimum distance to Serbia. The source for this variable is Google Earth. We also hand-collected data on whether there is a large forest near the village from the Serbian side, since the existence of the forest hampers the signal of Serbian radio. Finally, we control for county fixed effects. This is only a rough geographic control, since the baseline sample consists of only two counties, Vukovar-Sirmium and Osijek-

\footnotetext{
${ }^{10}$ We cannot use pre-war Census since it is not available in the electronic form and the paper version of the Census uses different geographic boundaries making the units incomparable.
} 
Baranja, with three additional counties, Slavonski Brod, Virovitica-Podravina, and PožegaSlavonia in the extended sample. In the robustness checks we use time and length of driving to the nearest location in Serbia collected using the Geocode Stata module as an alternative measure of distance to Serbia.

Sample. The region under study is located in the North-East of Croatia, bordering with Serbia to the East, Bosnia to the South, and Hungary to the North. The 139 villages in the baseline sample, indicated in Figure 1a by lighter dots, are the ones which we were able to visit in person and, hence, in which we collected radio reception data. Figure $1 \mathrm{~b}$ zooms into the baseline sample and presents the two radio reception measures (described below).

The extended sample includes the baseline sample, but also adds villages in Eastern Slavonia, Baranja and Western Srijem, which we were not able to visit, but which are within 75 kilometers of the Croatian-Serbian border. ${ }^{11}$ The additional villages in the extended sample are indicated by darker dots in Figure 1a. Figure 1c displays the signal strength for this larger sample of 417 villages, which includes all villages from counties of Osijek-Baranja and Vukovar-Sirmium as well as most villages from the counties of Slavonski Brod, ViroviticaPodravina, and Požega-Slavonia. We exclude villages with no data on population or zero population. The summary statistics for all village-level variables are in Table A1.

\section{The Serbian radio in Croatia}

The long diffusion of radio waves implies that the main alternative to Croatian radio for the majority of population in the border region are Serbian and Bosnian radio stations broadcasting from the other side of the border.

In Serbia, there are four public radio stations-RTS Radio 1, RTS Radio 2, RTS Radio 3, and Radio Belgrade 202 - as well as numerous private radio stations, like Radio Pink, Radio HIT, Radio S and Radio B92. RTS 1 broadcasts mostly news and current affairs programs, RTS 2 and RTS 3 broadcast at the same frequency at different times of the day, with the former oriented to art and the later to philosophical and intellectual programs, and Radio Belgrade 202 is more youth-oriented and broadcasts music programs.

With the exception of Radio B92, which was founded in 1989 with help of Soros foundation and USAID, Serbian radio stations are pro Serbian government, in part because of a centralized license allocation process. In particular, Serbian public radios aim at reinforcing the Serbian national identity (IREX 2010), with 9\% of coverage dedicated to neighboring countries including Croatia, focusing primarily on war and war crimes (Nedeljkovic, Dubravka and Bacanovic 2007, 214).

Given the political orientation and the coverage of controversial topics, it is not surprising that Croatian listeners can display a strong reaction to Serbian radio broadcast

\footnotetext{
${ }^{11}$ Villages located more than 75 kilometers away from the border have so low signal strength that reception of the Serbian radio is highly unlikely and therefore there is no meaningful variation among them. In the online Appendix, we show that the results for the extended sample are robust to using a more restrictive sample of villages within 50 kilometers from the border.
} 
(Nedeljkovic, Dubravka, and Bacanovic 2007, p. 219 and Udovicic 2005, p. 21). In addition, even non-political broadcast can potentially trigger ethnic animosity. For example, the most popular Serbian music style is the so-called turbo-folk, which was invented to support Milosevic rule, and is considered offensive by many Croats and Bosnians as it is associated with glorifying the war by Serbs (Kronja 2004).

Radio signal availability. Our identification strategy is based on comparing villages near the border in Croatia which receive Serbian radio to those which do not. To do so, we use two measures of reception of Serbian radio.

The first measure, which is available for the baseline sample of 139 villages, is based on hand-collected data obtained while travelling throughout the region in June 2009 and June 2010. In the center of each village (near the church or the war monument), we used a portable radio receiver to test whether the RTS Serbian stations were available. We count a radio station as available if its quality was good enough to listen to it based on subjective assessment of two people. The measure of availability is an indicator for whether at least one RTS radio station available. Figure 1b displays with a "+" sign the villages with reception according to this measure.

The second measure of reception of Serbian radio, which is available for the extended sample of 417 villages, is constructed using the location of RTS transmitters from the RTS website supplemented with technical characteristics of these transmitters from fmscan.org. Using these data, we determine the RTS signal strength in each of the Croatian villages. Similarly to Olken (2009) and Enikolopov et al. (2011), we apply the Irregular Terrain Model (Hufford 2002) to calculate the signal loss caused by physical distance and topography between transmitting and receiving locations. The model allows us to calculate the signal power for each village-transmitter pair using the geographical center of each village as the receiving location. Our measure of the signal strength for each village and each radio is the maximum of the signal powers across all transmitters. Figure $1 \mathrm{~b}$ shows that in the baseline villages signal strength and the measured reception line up, though the overlap is far from complete. Figure 1c shows the signal strength in the extended sample; the availability declines with the distance from the Serbian border, though in a jagged way, corresponding to the location of the transmitters, displayed in Figure 1a.

In what follows, we examine the impact of both the measured radio reception and the signal strength. In addition, the Online Appendix Table 6 presents the results using predicted radio availability constructed from a probit model which regresses radio reception on signal strength. The results for predicted radio availability are very similar to the ones for signal strength as villages are largely in the linear part of the S-shaped reception curve. Our baseline specification uses signal strength directly as in Olken (2009) as it does not require the estimation of the predicted availability parameters on a small sample of villages.

An important caveat to both measures is that the radio signal measures were taken in 2009 and 2010, whereas the election data are from 2007. Thus, our analysis is valid under the 
assumption that the radio reception did not change much in this period. We believe that this assumption is reasonable. The transmitter system of Serbian and Croatian radios was built during the times of Socialist Yugoslavia. Transmitters used by Serbian RTS radio stations are located in Serbia. During the war some of these transmitters were damaged, but the vast majority was repaired by the beginning of 2000s and was left largely unchanged since. In particular, transmitters, both Serbian and Croatian, remained the same in 2007-2010.

Measure of listening to Serbian radio. The measures of radio availability provide us with variation in whether Croatian villagers are able to listen to Serbian radio. But do the villagers where Serbian radio is available listen to the cross-border radio? If they do not, comparing towns with and without radio availability is a pointless exercise.

To answer this question, in December 2010 and January 2011 we conducted a face-toface survey of 70 individuals in 9 villages in the baseline sample: 4 villages without Serbian radio access (according to our measures), 2 villages with access to one Serbian radio, and 3 villages with access to two Serbian radios. We asked people on the central street of each village whether they could answer a few questions. The response rate was about $50 \%$. The questionnaire and a more detailed description of the survey are given in the Appendix B.

One of the questions we asked respondents was whether Serbian radio is available in their village. As Figure 2a shows, 87 percent of the respondents in villages that we categorize as having at least one Serbian radio respond affirmatively to the question, compared to 56 percent in villages that we categorize as having no reception. ${ }^{12}$ We also asked respondents how often they listen to Serbian radio. As Figure $2 \mathrm{~b}$ shows, in the villages with at least one Serbian radio station (according to our hand-collected measure), only 26 percent of the respondents state that they never listen to Serbian radio; whereas 32 percent state that they listen to Serbian radio at least once a week. In contrast, in the villages that we code as not having Serbian radio, 62 percent state that they never listen to Serbian radio; and only 16 percent state that they do so at least once per week. A linear probability model indicates a statistically significant difference between the two types of villages in the likelihood of listening to Serbian radios at least some times according to survey responses (Table 1).

Figure $2 \mathrm{c}$ indicates a similar pattern using the signal strength variable. The dots representing the villages in the survey indicate a positive relationship between signal strength and the measure of listening to Serbian radio; the pattern is similar for the question on availability of Serbian radio (Online Appendix Figure 1a). Columns 3 and 4 of Table 1 indicate that the relationship is statistically significant. We also asked whether respondents thought that other villagers listen to Serbian radio and got a similar pattern (Online Appendix Figure 1b). ${ }^{13}$

\footnotetext{
12 There are several potential explanations for the stated availability of Serbia radio in villages that we classify as not having such availability. First, our measure is crude and radio receivers differ in their power. We used a portable receiver without an amplifier, whereas amplifiers are fairly common. Second, there might be within village variation in the availability of weak signal. Third, there are different Serbian radios, broadcasted from different places, and the absence of the availability of RTS radios does not mean there is no Serbian radio in the village. Unfortunately, people do not remember the names of radios, so we could not ask specifically about RTS radio.

${ }^{13}$ Respondents were also asked if they are aware of the Serbian band Ribja Corba, whose songs are often played on
} 
The survey also provides information on the availability of Bosnian and Croatian radios allowing estimation of the patterns of substitution between radios. We find no significant differences across villages with and without Serbian radio in either the self-reported reception or the pattern of listening to Bosnian radio (Online Appendix Figures 2a and 2b). In contrast, we find some substitution away from Croatian radio when Serbian radio is available. Namely, while there is no difference across the two types of villages in the share reporting reception of Croatian radio, as all respondents report reception (Online Appendix Figure 3a), in villages with Serbian radio, respondents are less likely to listen to Croatian radio frequently (Online Appendix Table 1 and Online Appendix Figure $3 \mathrm{~b}$ and $3 \mathrm{c}){ }^{14}$

Overall, the survey findings indicate that a significant share of respondents listen to Serbian radio. In addition, the survey provides a reality check on our hand-collected radio availability measure and shows that our measure correlates well with survey measures of both the availability and listenership of Serbian radios. The survey also indicates that the extra time spent listening to Serbian radio crowds out some listening to Croatian radio (despite that the latter is always available).

\section{Empirical results on nationalism}

Determinants of radio availability. We first document the extent to which the measures of availability of Serbian radio correlate with control variables which may also be related to nationalistic sentiment and hence bias the estimates of media effects.

In Panel A of Table 2, we estimate the OLS regression

$$
\text { Availabilty_of_RTS_radio }{ }_{i}=\beta_{0}+\beta_{1} \mathbf{X}_{\mathbf{i}}+\phi_{r}+\varepsilon_{i}
$$

where Availability_of $R T S_{-}$radio ${ }_{i}$ is the measure of availability of Serbian radio stations, i.e., either an indicator variable for the measured availability or signal strength, $\mathbf{X}_{\mathbf{i}}$ is a vector of socioeconomic and demographic controls, and $\varphi_{r}$ are county fixed effects. We first examine the predictability of the measured availability of Serbia radio. Column 1 shows that only the share of people with higher education has a statistically significant effect on the measured reception of Serbian radio in the villages in the baseline sample. Importantly, as reported at the bottom of the Table, the full set of non-geographic controls is not jointly significant determinants of the availability of Serbian radio $(\mathrm{F}=0.99)$. Column 2 shows that the hand-collected measure of Serbian radio availability is, as expected, correlated with the signal strength of the Serbian radio constructed using transmitter information. This correlation replicates the pattern in Figure $1 \mathrm{~b}$.

Hence, while signal strength predicts availability of radio signal, other demographics, which may be correlated with nationalistic behavior, do not. This finding is consistent with the availability of Serbian radio being idiosyncratic. One may argue, however, that this is a weak test due to the possibility that, while not jointly significant, the control variables associated with

Serbian radio. We find that almost all respondents in both types of villages are aware of this band (as shown in Online Appendix Figure 1c).

${ }^{14}$ There is no variation in the likelihood of listening to the Croatian radio at least sometimes as nearly all respondents report doing so. 
nationalism positively co-vary with radio availability. Panel B of Table 2 presents a stronger test inspired by Altonji, Elder, and Taber (2005). We regress the ultimate outcome variable nationalistic vote share - on an index of predicted availability of RTS radio from specification (1). This univariate regression allows for a higher-power test of how the observables that are correlated with radio availability are correlated with the outcome of interest. Column 1 in Panel B provides no statistical evidence of a positive correlation, which could lead to an upward bias in the main specification (to the extent that the observables are positively correlated with the unobservable confounds). Columns 3 and 4 in Panel A of Table 2 focus on the signal strength. We find that the signal strength of Serbian radio is related (negatively) to the distance to Serbia, to the share of people between 41 and 60 years of age (also negatively), to the economically active population (positively), and to the number of individuals disabled in the war of independence. Unlike in the case of measured availability, the non-geographic controls significantly predict radio availability $(\mathrm{F}=3.09$ and $\mathrm{F}=5.65)$. The Altonji-Elder-Taber test presented in Panel B shows that the index of observables is negatively (insignificantly) correlated with voting, suggesting if anything a negative bias in the coefficients.

In Online Appendix Table 2, we implement the Altonji-Elder-Taber test separately by three groups of controls: geographic, census, and additional controls, and document a negative correlation between an index for each group of controls and the nationalistic vote share. The correlation is insignificant when we predict the Serbian radio availability and is significant in the case of predicting signal strength. The fact that none of the three indices has positive correlation with nationalism irrespective of the Serbian radio measure used bolsters the view that the main estimates are unlikely to be biased upward.

Effect on voting for the extreme nationalistic parties. To test whether Serbian radio affects voting behavior, we estimate the OLS regression

$$
d e p_{-} \operatorname{var}_{i}=\beta_{0}+\beta_{1} \cdot \text { Availabiliy_of_RTS_radio }{ }_{i}+\beta_{2} \mathbf{X}_{\mathbf{i}}+\phi_{r}+\varepsilon_{i}
$$

where $d e p \_v a r_{i}$ is the relevant political variable (vote share or turnout) in village $i$ for the 2007 Parliamentary (Sabor) elections, Availability_of ${ }_{-} R T S_{-}$radio $_{i}$ is the measure of availability of Serbian radio stations, i.e., either an indicator variable for the measured availability or signal strength, $\mathbf{X}_{\mathbf{i}}$ is a vector of socioeconomic and demographic controls, and $\varphi_{r}$ are county fixed effects. We weight the observations by the number of registered voters in 2007 and cluster the standard errors at the municipality (općina) level.

Table 3 presents the results of estimation of equation (2) for the vote share of extremely nationalistic parties in the baseline sample with no controls (Column 1), with geographic and Census demographic controls (Column 2), and with all controls (Column 3). In the specification with most controls (Column 3), the availability of Serbian radio increases the vote share for the extreme nationalist parties by 2.3 percentage points relative to a baseline vote share of 7 percentage points, a statistically and economically significant effect. Column 1 in Online Appendix Table 3 reports the coefficient on all the control variables.

A key concern is that the availability of Serbian radio could proxy for (unobservable) 
confounding variables that are positively correlated with nationalistic sentiment and hence bias upward the correlation between radio availability and nationalistic vote share. Above, we have shown that there is no significant correlation of the radio availability variable with observables (Panel A of Table 2), not even when we take a combination of controls (Panel B of Table 2). A complementary test proposed by Altonji, Elder, and Taber (2005) is to examine how the introduction of control variables affects the results. To the extent that the observable controls are positively correlated with the unobservable confounds, if there is an upward bias in the estimates due to an omitted variable, adding controls should lower the point estimate, since they reduce the impact of the bias on the estimates. When we apply this test, we find no evidence that a bias drives the results upward. The point estimate of the effect of radio remains essentially identical with the addition of controls. While of course it is possible that our control variables are not positively correlated with the unobservables which bias the results, the controls include plausible correlates of nationalism (such as an indicator for importance during the war) and overall do a good job of predicting the nationalistic vote share, with an R-squared of 0.53 (Column 3). It is hence comforting that adding these variables does not affect the estimated results.

One may worry that the estimated effect of exposure to Serbian radio reflects the impact of an outlier village, especially given the small sample of 139 villages in the baseline sample, of which 16 villages are identified as having reception of Serbian radios. To address this concern, Figure 3a provides a comparison of the c.d.f. of the vote share for the extreme nationalistic party in the villages with and without reception of Serbian radio, after taking control variables into account. (We regress the vote share on all the control variables in Column 3 except the radio reception, and plot the residuals evaluated at the mean; a similar plot, but without taking controls into account, is presented in Online Appendix Figure 4a). The vote share for the villages with Serbian radio nearly first order stochastically dominates the vote share for villages with no Serbian radio. A Kolmogorov-Smirnov test rejects the hypothesis of the equality of distributions with controls with a p-value of 0.006 . Figure $3 b$ provides evidence on the map of a positive correlation between the availability of Serbian radio and the residual vote share for the extreme nationalist parties (in deciles) after accounting for controls. Altogether, Figures 3a-3b show that the results are not due to a single outlier but rather to a pronounced pattern.

Returning to Table 3, the next specification (Column 4) decomposes the effect of availability of one Serbian radio versus multiple Serbian radios. In the 9 villages where multiple (RTS) Serbian radios are available, the audience is more likely to listen to Serbian content (intentionally or accidentally) and the reception of the Serbian channels is likely to be better. Indeed, these villages are associated with an (insignificantly) larger impact on nationalistic voting than the villages with one radio.

The estimates so far have made use of the hand-recorded measure of Serbian radio availability. In Columns 5-7 we present the parallel specifications using signal strength. In the most controlled specification, we again find a significant effect of signal strength on the nationalist vote share. Also, the addition of controls is associated with larger estimates. In 
Figure 4 we provide a graphical illustration. For each village, we plot the residual signal strength and the residual vote share, after taking controls into account, and find a monotonic pattern.

Robustness. Table 4 documents the results of various robustness checks, both for the measured reception measure and the signal strength measure.

First, we show that the results are unlikely due to the fact that towns with overall better radio reception may have unobservable features that are associated with nationalism. We examine the impact of reception of Hungarian radio on the nationalistic vote share. Given the lack of hostilities with Hungary and the fact that very few Croats speak or understand Hungarian, we expect no casual impact on nationalism. Indeed, we find no impact of this radio, and controlling for their availability does not affect the main estimates.

We also consider the impact of the signal strength of two major Croatian radios, the Radio HRT group and the Croatian Catholic Radio. One may worry that villages with reception of Serbian radio differ also in reception of Croatian radios (despite survey evidence suggesting that all villages have reception of Croatian radio). We find that controlling for the signal strength of these radios has no impact on the estimated effect of Serbian radio. ${ }^{15}$

We then consider the impact of spatial correlation on our estimates. The level of clustering in our baseline estimation allows for correlation of error term among villages in the same municipality, but not across these geographical units. In order to account for spatial correlation, in Columns (4) and (5) we present the main results with standard errors corrected with the Conley (1999) procedure. ${ }^{16}$ The corrected standard errors are if anything slightly lower once adjusted for spatial correlation and, thus, our results are robust.

One may also be concerned that the results may be driven by proximity to Serbia, rather than by radio availability and that the log-linear control for distance to the Serbian border may not be enough. To address this issue we include controls for a fifth-order polynomial of distance to the border, as well as for driving time to Serbia. In addition, we check if the results are robust to measures of exposure to military conflict during the Croatian-Serbian conflict. We use information on the location of war incidents from the Armed Conflict Location and Event Dataset. For each village we calculate the number of conflict events that occurred within $3 \mathrm{~km}$ or each village. ${ }^{17}$ The results turn out to be very similar if we add these additional controls (Columns 7 and 8).

Finally, the results are robust to a nearest-neighbor matching estimator, where we compute the average treatment on the treated by finding the 5 control villages which are the closest to each of the treated villages (that is, each village with radio reception) (Column 9).

Online Appendix Table 4 also shows that the results are essentially identical if we: (i)

\footnotetext{
${ }^{15}$ We find some evidence that stronger signal strength for the HR radio lowers the nationalistic vote share, with no such effect for the Catholic Croatian radio.

${ }^{16}$ The original method in Conley (1999) was extended to allow for weighting.

${ }^{17}$ The results are similar if we use as a measure of conflict exposure the distance to the closest conflict event, the incidence of conflict within $1 \mathrm{~km}, 3 \mathrm{~km}, 5 \mathrm{~km}$, and $10 \mathrm{~km}$ radii around each village and the number of the conflict events within these radii.
} 
consider only the vote for the main nationalistic party HSP (without vote for HP-HPP and HCSP) as dependent variable; (ii) control for the location of the Serbian Krajina. Overall, we find sizable and robust cross-border media effects. We discuss the magnitude of the estimated effects below in the subsection on persuasion rates.

Other voting outcomes. Table 5 displays the results for other political outcomes, reproducing the baseline estimates from columns 3 and 7 of Table 3 in the first two columns, with the corresponding graphical evidence in Online Appendix Figures $4 b-4 d$. The availability of Serbian radio has a negative effect on the vote share for the moderate nationalistic parties (Columns 3 and 4); the effect is especially pronounced in the specification with signal strength. There is some evidence that the exposure to Serbian radio increased the vote share for the Social Democratic party (Columns 5 and 6). An interpretation of this result is that exposure to Serbian radio made Croatian voters more nationalistic at the margin, shifting some voters from the moderate nationalist party to the extreme nationalist parties, while polarizing the electorate, which leads to higher vote share for the Social Democratic party. We find no evidence of an effect on turnout (Columns 7 and 8), though these results are more tentative, as the measure of listed voters is noisy.

Extended sample analysis. The analysis so far focused on the sub-sample of villages that we visited (baseline sample). We also analyze the extended sample of 417 villages within 75 kilometers of the Croatian-Serbian border. In this larger sample, we do not have a direct measure of radio availability and hence focus on the specification with signal strength.

The results are largely robust to extending the sample as reported in Table 6 . The signal strength of Serbian radio is associated with significantly higher vote share for the extreme nationalist parties (Column 2), a decrease in the vote share for moderate nationalist parties once controls are included (Column 4), an increase of the vote share for the social-democratic party (Column 6), and a decrease in turnout (Column 8). Regarding the main result on the vote share of extreme nationalist parties (Column 2), the estimate is somewhat smaller than the comparable estimate for the baseline sample (column 6 in Table 3), though not significantly so. Also, as in the baseline sample, the estimate with controls is larger than the estimate without controls, suggesting that potential omitted variables are not likely to bias the estimates in our favor (provided that unobservables positively correlate with available control variables). Online Appendix Table 5 shows that the results are very similar if we restrict the sample to villages within 50 kilometers of the border.

Heterogeneity of Effects. We examine the heterogeneity of the impact of exposure to Serbian radio on voting by adding to specification (2) an interaction of the availability and signal strength variables with a particular control variable. As our sample is small, we include interactions with one variable at a time. Online Appendix Table 7, Panels A and B show that the only consistent pattern is that the effect tends to be smaller in villages with more disabled during the war of independence and more important role in the war. In these villages, nationalism is higher most probably because of the vivid memories of the war experience, and, therefore, the 
media message is likely to be infra-marginal.

Effect on graffiti. As an alternative measure of nationalism, we use the presence of graffiti ethnically disparaging of Serbs in public spaces in the village (see Figure 5). Using a probit specification with equal weighting (Table 7), we find that in villages with Serbian radio the probability of ethnically offensive graffiti in the streets is 35 to 40 percentage points larger, that is, about double as compared to the villages with no Serbian radio, a statistically significant difference. The addition of controls has a small impact on the estimates. We find similar results using the continuous measure of signal strength, and the results are similar if we use a linear probability model (Online Appendix Table 8). These results provide evidence that Serbian public radio increases the expressions of Croatian nationalism beyond the voting booths.

Persuasion rates. To interpret the magnitudes of the impact of media availability on voting for extreme nationalist parties, we evaluate the results in terms of persuasion rate (DellaVigna and Kaplan, 2007). The persuasion rate is the fraction of the audience of a media outlet who are convinced to change their behavior (in this case, their vote) as a result of being exposed to this media outlet.

To compute the persuasion rates, one needs an estimate of the share of individuals listening to the media in question (Serbian radio) in the treatment group (villages with Serbian radio) and in the control groups (villages without Serbian radio). As not all residents in a village with reception of Serbian radio listen to it and some residents in villages with no reception of Serbian radio (according to our measure) do listen to it, we use survey responses to estimate the "first stage." The estimates in Table 1 imply that the exposure to Serbian radio content is 31 percentage points higher in the villages with at least one Serbian radio available (Column 2 of Table 1). In addition, a unit increase in the signal strength of Serbian radio is associated with a 51-percentage point increase in exposure (Column 4 of Table 1).

To compute a persuasion rate based on the dichotomous measure of availability of Serbian radio, we use the following formula from DellaVigna and Kaplan (2007): $f=\frac{v_{T}-v_{C}}{e_{T}-e_{C}} \frac{t_{T}}{1-v_{C}} \cdot v_{T}$ and $v_{C}$ are the votes for ultra-nationalists in villages with and without Serbian radio, respectively, $e_{T}$ and $e_{C}$ are the exposures to Serbian radio in villages with and without Serbian radio, respectively, and $t_{T}$ is the turnout in villages with Serbian radio. Turnout is not affected by Serbian radio and is equal to $t_{T}=t=56.2 \%$. The difference in exposure is estimated from the survey data and equals to $\hat{e}_{T}-\hat{e}_{C}=0.313$ (Column 2 of Table 1). The impact on voting equals $\hat{v}_{T}-\hat{v}_{C}=0.0226$ (Column 3 of Table 3 ) and the predicted share of vote for ultra-nationalists in the absence of Serbian radio is $\hat{v}_{C}=0.057$. Thus, the persuasion rate is $f=(0.0226 * 0.562) /(0.313 * 0.943)=4.3 \%$.

Alternatively, we can compute the persuasion rate based on the continuous measure of signal strength using the formula from Enikolopov et al. (2011):

$$
f=\frac{1}{1-v_{0} t_{0}}\left(t \frac{d v}{d e}+v \frac{d t}{d e}\right)=\frac{1}{1-v_{0} t_{0}}\left(t \frac{d v}{d a} / \frac{d e}{d a}+v \frac{d t}{d e}\right)
$$


Here $v_{0} t_{0}$ is the number of people who would vote for ultra-nationalists in the absence of Serbian radio; $v$ and $t$ are the vote share of ultra-nationalists and the voter turnout in Opštinas with $e$ exposure to the Serbian public radio; $\frac{d v}{d a}$ is the effect of $d a$ change in the signal strength of Serbian radio on the vote share; $\frac{d e}{d a}$ is the effect of a $d a$ change in the signal strength on the exposure; and $\frac{d t}{d e}$ is the effect of de change in exposure on turnout. Our results with signal strength yield that $v_{0} t_{0}$ equals 4.3 percent. This implies that 95.7 percent of Croats could, in principle, be convinced by the radio's message. From column 7 of Table 3 , we get that $\frac{d v}{d a}$ is equal to 2.404. The estimated effect of signal strength on the exposure $\frac{d e}{d a}$ is 51.3 (Column 4 of Table 1). As there is no effect on turnout, $t$ does not depend on $e$ and hence the second term in parentheses in equation (3) is 0 . The implied persuasion rate is $f$ $=0.957 * 0.562 *(2.404 / 51.3)=2.7 \%$. These results are slightly smaller than the results obtained using a binary measure of radio availability above and are on the lower end of estimates in the literature of persuasion effects (DellaVigna and Gentzkow 2010).

\section{Laboratory Experiment}

To provide additional evidence on the effect of Serbian radio on the nationalistic sentiment of Croats, we designed a laboratory experiment in which we exposed Croatian students from the region to different remixes of news and music from radio programs typically broadcasted in the region. The experiment took place in December 2010 with 80 undergraduate Croatian students from the University of Vukovar as subjects.

We randomized the students into three groups and placed them in three different classrooms. Each group listened to a fifteen and a half minute remix of radio recordings, consisting of three recordings of news broadcasts separated by two songs of approximately the same length. The first two news broadcasts were common to all three groups and drawn from a Croatian radio station. In contrast, the two songs and the third news broadcast differed between group assignments: The first group listened to fragments from Croatian radio only and the two popular Croatian songs. The second group listened to a fragment from the independent Serbian radio B92 and two popular Serbian songs. The third group listened a fragment from the Serbian Public RTS radio (substantially more nationalistic that B92) and another two popular Serbian songs. The songs were chosen to be representative of those typically played on Croatian radio, B92 radio, and RTS radio, respectively. The songs played in the two Serbian radio treatments are modern, but have direct references to Serbian national folklore, easily identifiable by Croats. In addition, one of the songs in the RTS treatment has a direct reference to the Serbo-Croatian conflict, as it is devoted to a former Serbian paramilitary commander accused of war crimes in Croatia. None of the news broadcasts talk about the Serbo-Croatian conflict. The two Serbian 
radio treatments, however, mention the investigations of Yugoslavian war crimes by Serbian prosecutors and the international war crime tribunal in connection to Kosovo (with no relation to Croatia). All news broadcasts were recorded from the respective radio stations one month before the experiment. The summary of the content of the three radio remixes is presented in Online Appendix Table 9, with the full transcript in Online Appendix C.

After listening to the remixes, subjects were given five minutes to complete a questionnaire about basic socio-demographic information, the content of the remix they listened to, and attitudes toward different ethnic groups. Overall, the experiment took about 30 minutes and participants received 20 kunas (slightly less than $\$ 4$, equal to approximately an hourly wage). The questionnaire is also presented in the Online Appendix C.

This design is modeled upon the work of, among others, Iyengar (1995), who used it to study the impact of political advertising on political attitudes. While a downside of this design is that survey responses can be subject to demand effects, an important advantage is that we can guarantee random assignment of information and examine the consistency of experimental results with the field evidence.

The first question after the exposure to radio recordings was a "feeling thermometer" which asks for the subject's attitude towards different ethnic groups -- Serbs, Bosnians, Hungarians, and Rusini, -- on a scale from 0 to 100. The second question asked whether respondents would agree to work with someone of each ethnic group. As Figures $6 \mathrm{a}$ and $6 \mathrm{~b}$ show, the exposure to Serbian radio had a dramatic effect of inducing less positive attitudes towards Serbs and reducing substantially the stated likelihood to work with a Serbian person. This effect is more pronounced for the exposure to the RTS radio, which is the focus of our paper, compared to the exposure to the less-nationalistic B92 radio. There is no effect on attitudes towards other ethnic groups, as expected.

We also asked whether respondents would agree to send their children to school together with children from different ethnic groups; whether respondents would agree if their children got married to representatives of different ethnic groups, and whether they would agree if their children have people of different groups as their best friends (see Online Appendix Figures 4a$4 \mathrm{c})$. For all of these questions, the RTS radio treatment made respondents more negative about the Serbs, but not about representatives of the other ethnic groups. For two of these questions, the effects of treatment with RTS and B92 radios are quite similar, while for the other question, the effect of B92 treatment is much smaller.

We also asked subjects to rank political parties with higher rank indicating higher preference. As Figure 6c shows, we find a modest (not statistically significant) increase in the rank for the extreme nationalist party, a significant increase in the rank for the moderate nationalist parties, and a decrease in the rank of the Social Democratic party. The impact of exposure to RTS radio on the vote share of the extreme nationalistic party, though not significant, is consistent with the field evidence. The pattern of substitution for the other parties instead differs from the field evidence where we find substitution away from the moderate 
nationalistic party. One possible explanation for this partial discrepancy is the difference in political preferences between the young college-educated laboratory subjects and the overall Croatian population. Indeed, in this sample the preference for the extremely nationalistic party is higher than in the general population. Consistent with this interpretation, in the field evidence we find that the coefficient on the interaction of radio availability with the share of older population is negative and significant in regressions explaining vote for moderate nationalists (results available from the authors upon request).

Overall, the experimental findings suggest that even a short exposure to the type of content featured in the Serbian RTS radio (such as the song devoted to a Serbian alleged war criminal) affects significantly attitudes towards Serbs in the direction of increased nationalism and anti-Serbian sentiment. There is also some evidence of an effect on the preference for extremely nationalistic parties, although with a different pattern with respect to the other parties relative to the field evidence. An important finding is that, with respect to the attitude question, subjects treated with Serbian nationalistic public radio, RTS, which is openly hostile to Croatia, were substantially more affected compared to those treated with B92 Serbian radio, which also features Serbian news and music, but is neutral towards Croats. This evidence is suggestive of the mechanism behind the effect. It is more likely that Serbian public radio catalyzes ethnic animosity towards Serbs because it reminds Croats about current Serbian nationalism and antiCroatian rhetoric rather than because it reminds them of the proximity to their former war enemy. However, the mechanism behind a short-run spontaneous reaction to being exposed to a nationalistic song of the former enemy could be different from the mechanism of formation of long-term political preferences.

\section{Conclusion}

This paper documents the effect of Serbian public radio on the voting behavior and nationalistic anti-Serbian sentiment of Croats in Eastern Slavonia, Baranja and Western Srijem, a post-conflict region of modern Croatia on the border with Serbia. We find that the exposure to the Serbian public radio convinces some Croats to switch to voting for ultra-nationalist parties from voting to moderate nationalist party. In addition, exposure to Serbian public radio increases the incidence of ethnically-offensive graffiti on public buildings in the center of their villages. The results of a laboratory experiment confirm that Serbian public radio causes an increase in anti-Serbian sentiment among Croats.

Our results indicate that foreign media can have substantial cross-border effects in countries characterized by post-conflict ethnic tensions such as Croatia. These findings are likely to apply more generally to areas of past conflict with similar languages and overlapping media markets. This suggests that peaceful relations between neighboring countries depend in part on the content of media programming, and the extent of media overlap. Hence, nation-building efforts implicit in the nationalistic content of the media (in this case, the Serbian radio) can have important spillovers on the persistence of peace between countries. 


\section{References}

Acemoglu, Daron, and Alexander Wolitzky (2012) "Cycles of Distrust: An Economic Model," working paper

Altonji J., T. Elder, and C. Taber (2005) Selection on Observed and Unobserved Variables: Assessing the Effectiveness of Catholic Schools. Journal of Political Economy, 113(1), 151-184.

Allport, G. W. (1954) The nature of prejudice. Addison-Wesley Pub. Co., Boston, MA.

Barnhardt S. (2009) Near and Dear? Evaluating the Impact of Neighbor Diversity on Inter-Religious Attitudes, mimeo. Harvard University.

Blattman, Christopher, 2009, "From Violence to Voting: War and Political Participation in Uganda", American Political Science Review 103: 231-47.

Blattman, C. and E. Miguel (2010). "Civil War," Journal of Economic Literature, American Economic Association, vol. 48(1): 3-57.

Boisjoly J., G. Duncan, J. Eccles, M. Kremer, and D. Levy (2006). Empathy or Antipathy? The Consequences of Racially and Socially Diverse Peers on Attitudes and Behavior, American Economic Review, 96(5): 18901906.

Bursztyn, L. and D. Cantoni (2011) Clueless? The Impact of Television on Consumption Behavior. Working paper.

Butler, D. M. and A. L. De La O (2011) The Causal Effect of Media-Driven Political Interest on Political Attitudes and Behavior, Quarterly Journal of Political Science: Vol. 5:No 4, pp 321-337.

Caselli, F., M. Morelli and D. Rohner (2012) The Geography of Inter-State Resource Wars," mimeo, London School of Economics.

Chassang, S. and G. Padró i Miquel (2010) "Conflict and Deterrence under Strategic Risk," The Quarterly Journal of Economics 125 (4): 1821-1858.

Childs, H. L. (1972) Propaganda and Dictatorship: A Collection of Papers. New York: Arno Press.

Conley, T.G. (1999) GMM Estimation with Cross Sectional Dependence. Journal of Econometrics 92, 1-45.

DellaVigna, S., and M. Gentzkow (2010) Persuasion: Empirical Evidence. Annual Review of Economics 2, 643669

DellaVigna, S. and E. Kaplan (2007) The Fox News effect: Media bias and voting. Quarterly Journal of Economics 122(3), 807-860.

Dovidio, J. F., P. S. Glick, and L. A. Rudman (2005) On the nature of prejudice: fifty years after Allport. WileyBlackwell, New York City, NY.

Dube, Oeindrila, and Juan Vagras (2012) “Commodity Price Shocks and Civil Conflict: Evidence from Colombia," working paper

Dube, Oeindrila, and Suresh Naidu (2011) "Bases, Bullets and Ballots: the Effect of U.S. Military Aid on Political Conflict in Colombia," working paper

Durante, R., and B. Knight (forthcoming) Partisan Control, Media Bias, and Viewer Responses: Evidence from Berlusconi's Italy. Journal of European Economic Association.

Enikolopov, R., M. Petrova and E. Zhuravskaya (2011) Media and Political Persuasion: Evidence from Russia. American Economic Review, 101(7), 3253-85.

Esteban, J. and D. Ray (2008) "On the Salience of Ethnic Conflict," American Economic Review, 98, 2185-2202.

Folke, O. (2011) Shades of Brown and Green: Party Effects in Proportional Election Systems. Mimeo, Columbia University.

Gentzkow, M. (2006) Television and voter turnout. Quarterly Journal of Economics 121(3), 931-972.

Gentzkow, M. and J. M. Shapiro (2004) Media, Education, and Anti-Americanism in the Muslim World. Journal of Economic Perspectives. 18(3).

Gentzkow, M. and J. M. Shapiro (2011) Ideological Segregation Online and Offline, Quarterly Journal of Economics. 126 (4)

Gerber A., Karlan D., Bergan, D. (2009) Does the media matter? a field experiment measuring the effect of newspapers on voting behavior and political opinions. American Economic Journal: Applied Economics, 1(2), 35-52.

Greenberg, Robert D. (2004) Language and Identity in the Balkans. Oxford University Press.

Hainmueller, J. and H. Kern (2009) Opium for the masses: How foreign free media can stabilize authoritarian regimes. Political Analysis, 17, 377-399. 
Hess, G. and A. Orphanides (1995) 'War Politics: An Economic rational-voter framework,' American Economic Review, 85: 4, 828-846

Hislope, R. (1996) Intra-Ethnic Conflict in Croatia and Serbia: Flanking and the Consequences for Democracy. East European Quarterly, 30, pp. 471-494.

Hockenos P. (2003) Homeland Calling: Exile, Patriotism and the Balkan Wars. Cornell University Press: Ithaca, NY.

Hufford, G.A. (2002) The ITS Irregular Terrain Model, Version 1.2.2 the Algorithm. Available: http://flattop.its.bldrdoc.gov/itm.html.

IREX (2010) Media Sustainability Index 2010- Serbia. International Research \& Exchanges Board.

Iyengar, S. (1995) Going Negative: How Political Advertisements Shrink and Polarize the Electorate. Free Press.

Jackman, R., and Volpert, K. (1996) Conditions favoring parties of the extreme right in Western Europe. British Journal of Political Science, 26, 501-521.

Jackson, M.O. and M. Morelli (2007) "Political Bias and War," American Economic Review, 97:4, 1353-1373.

Jackson, M. and M. Morelli (2011) The Reasons for Wars - an Updated Survey. In the Handbook on the Political Economy of War, Chris Coyne and Rachel Mathers (eds.), Elgar Publishing, Cheltenham, the UK.

Saumitra Jha (2008) “Trade, Institutions and Religious Tolerance: Evidence from India," Stanford University Graduate School of Business Research Paper No. 2004

Knight B., Chiang C. (2011) Media bias and influence: Evidence from newspaper endorsements. Review of Economic Studies, 78(3), 795-820.

Kronja, I. (2004) Turbo Folk and Dance Music in 1990s Serbia: Media, Ideology and the Production of Spectacle. The Anthropology of East Europe Review 22(1), 103-114.

Kurspahić, K. (2003) Prime Time Crime: Balkan Media in War and Peace. Washington DC: United States Institute of Peace.

Laqueur, W. (1997) Fascism: Past, Present, Future. New York: Oxford Univerisity Press.

Lawson, C. and J. A. McCann (2005) Television news, Mexico's 2000 elections, and media effects in emerging democracies. British Journal of Political Science 35(1), 1-30.

MacDonald, David Bruce (2002) Balkan Holocausts? Serbian and Croatian Victim- Centred Propaganda and the War in Yugoslavia. Manchester: Manchester University Press.

Miguel, Edward, and John Bellows (2009) War and Local Collective Action in Sierra Leone" Journal of Public Economics, 93(11-12), 1144-1157

Nedeljkovic V., Dubravka, and Visnja Bacanovic (2007) Monitoring and analysis of TV news programs in SerbiaRTS, RUV and TV B92: From emotional approach to the fate of Kosovo to progressive civil activism. In Indicator of Public Interest: TV prime time domestic news-monitoring and analysis of TV news programs in 10 SEENPM countries, ed. Radenko Udovicic. Sarajevo: Media Plan Institute.

Olken B. (2009) Do TV and Radio Destroy Social Capital? Evidence from Indonesian Villages. American Economic Journal: Applied Economics 1 (4), 1-33.

Pettigrew, T. F. and L. R. Tropp. (2006) A Meta-Analytic Test of Intergroup Contact Theory. Journal of Personality and Social Psychology, 90(5) : 751-83.

Peruško, Z. and Jurlin, K.(2006) The Croatian Media Market: Regulation and Concentration Trends, unpublished study for the Media Division of the Council of Europe.

Rohner, Dominic, Mathias Thoenig, and Fabrizio Zilibotti (2012) "Seeds of Distrust: Conflict in Uganda" CEPR Discussion Paper No. DP8741.

Skiljan, D. (2000) Semantics of war. In N. Skopljanac Brunner, S. Gredelji, A. Hodzic, \& B. Kristofic (Eds.), Media and war. Zagreb, Croatia: Centre for Transition and Civil Society Research.

Smajlović, L. (1997) Media in the Federal Republic of Yugoslavia, IREX Report.

Snyder, J. and Strömberg, D. 2010. Press Coverage and Political Accountability” Journal of Political Economy 118(2), 355-408.

Strömberg, D. (2004) Radio's impact on public spending. Quarterly Journal of Economics 119(1), 189-221.

Sunstein, C. R. (2001) Republic.com. Princeton, N.J.: Princeton University Press.

Thompson, M. (1994) Forging War:The Media in Serbia, Croatia and Bosnia-Herzegovina, London: Article 19.

Udovicic R. (2005) Battling political frustration, mediaonline, Available: http://www.mediaonline.ba/en/?ID=343. 
UNCE (1994) Final report of the United Nations Commission of Experts established pursuant to security council resolution 780 (Annex III.A Special forces) Available : http://www.ess.uwe.ac.uk/comexpert/anx/IIIA.htm\#III.D.

Van Laar, C., S. Levin, S. Sinclair, and J,. Sidanius (2005). The Effect of University Rommate Contact on Ethnic Attitudes and Behavior. Journal of Experimental Social Psychology, 41 : 329-245.

Voerman, G., P. Lucardie (1992) The extreme right in the Netherlands: The centrists and their radical rivals, European Journal of Political Science, 22/1, 35-54.

Voigtländer, Nico, and Hans-Joachim Voth (2012) "Persecution Perpetuated: Medieval Origins of Anti-Semitic Violence in Nazi Germany," forthcoming in Quarterly Journal of Economics

Voors, Maarten J., Eleonora E. M. Nillesen, Philip Verwimp, Erwin H. Bulte, Robert Lensink, and Daan P. Van Soest. 2012. "Violent Conflict and Behavior: A Field Experiment in Burundi." American Economic Review, 102(2): 941-64.

Yanagizawa, D. (2009) Propaganda and Conflict: Theory and Evidence from the Rwandan Genocide. Working paper.

Zaller, J. (1992). The Nature and Origins of Mass Opinion. Cambridge, UK: Cambridge University Press. 
Figure 1a. Map of the area with the baseline and extended samples of villages

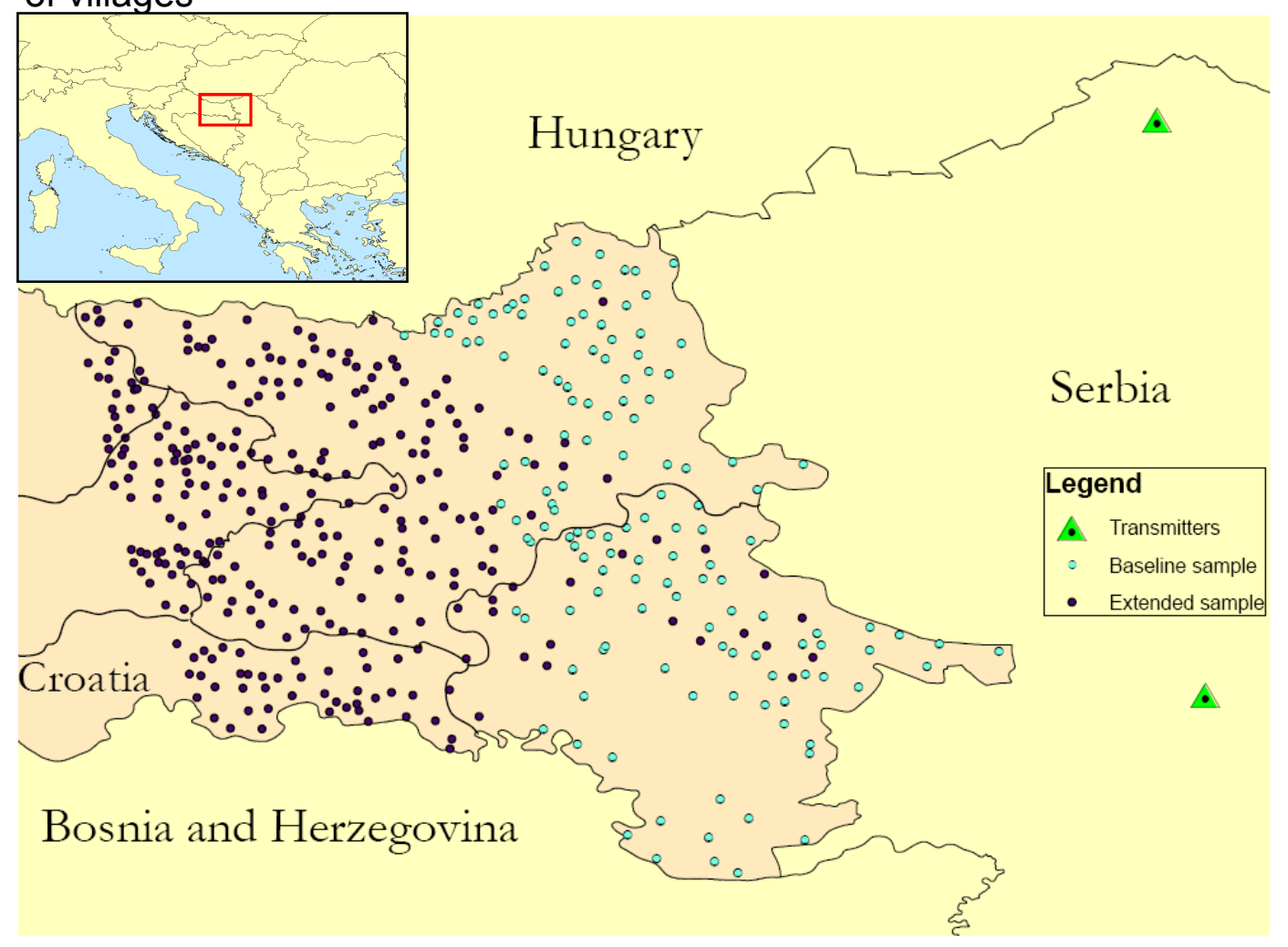

Figure 1b. Map of the area with the baseline sample of villages showing both the measured and the predicted reception of Serbian radio.

Radio availability

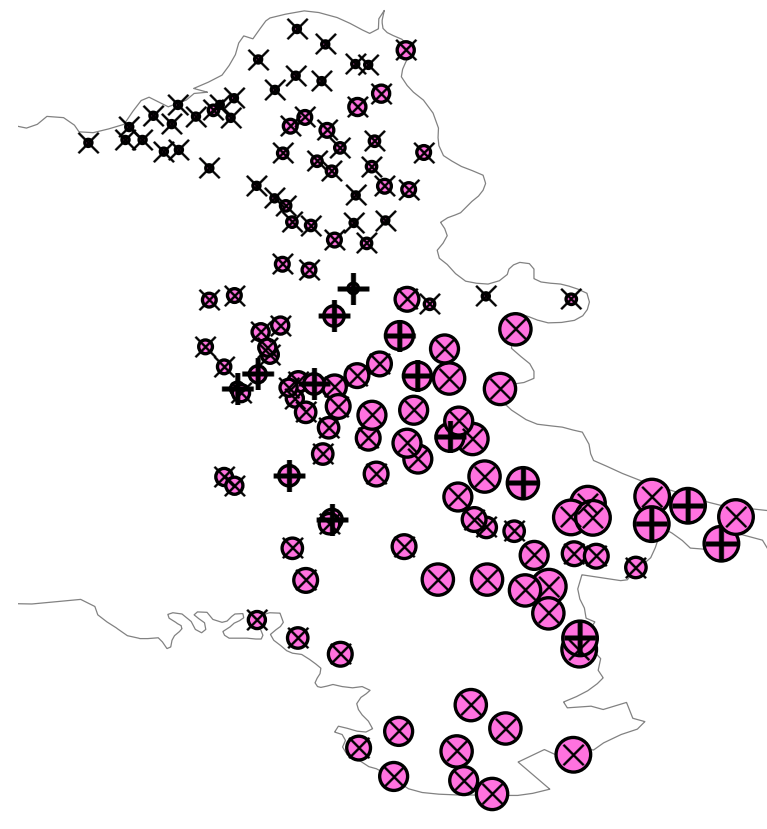

$$
\begin{array}{r}
\times \quad 0 \\
+\quad 1
\end{array}
$$

\section{Signal strength} deciles
- $-0,046748--0,029147$
- $-0,029146--0,022358$
- $-0,022357--0,011738$
- $-0,011737--0,009649$
○ $-0,009648--0,007378$
O $-0,007377--0,006068$
O $-0,006067--0,004586$
O $-0,004585--0,001339$
O $-0,001338-0,002410$
O $0,002411-0,014665$
Croatian border 
Figure 1c. Map of the area with the extended sample of villages, showing the predicted reception of Serbian radio.

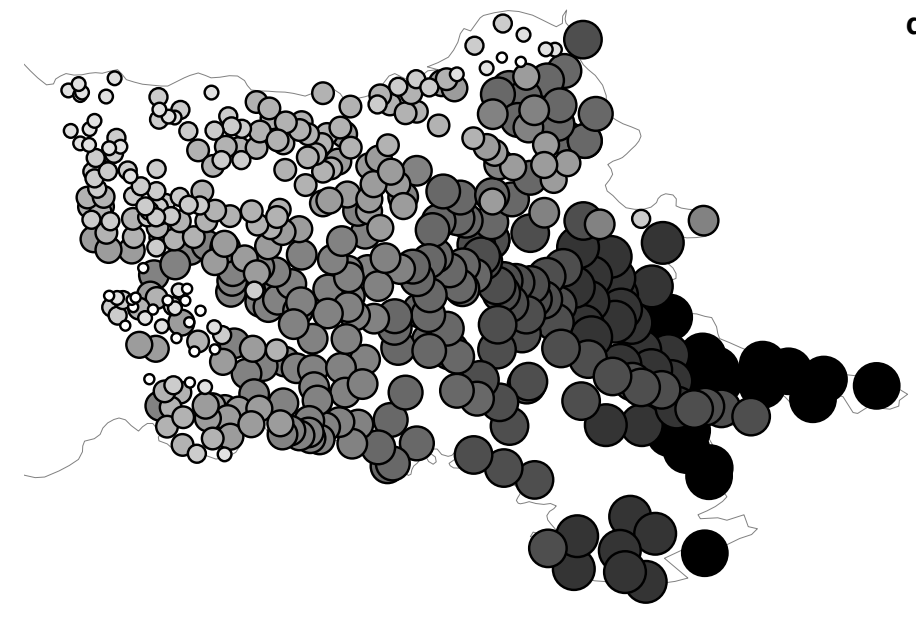

\section{Signal strength (ext. sample)} deciles

- $-0,062151--0,042112$

○ $-0,042111--0,033930$

O $-0,033929--0,029119$

O $-0,029118--0,024806$

O $-0,024805--0,018763$

O $-0,018762--0,012659$

$-0,012658--0,008522$

$-0,008521--0,004241$

$-0,004240-0,001037$

$0,001038-0,014665$

Croatian border 
Figure 2a. Reported reception of Serbian radio (survey response), as function of availability of Serbian radio in village.

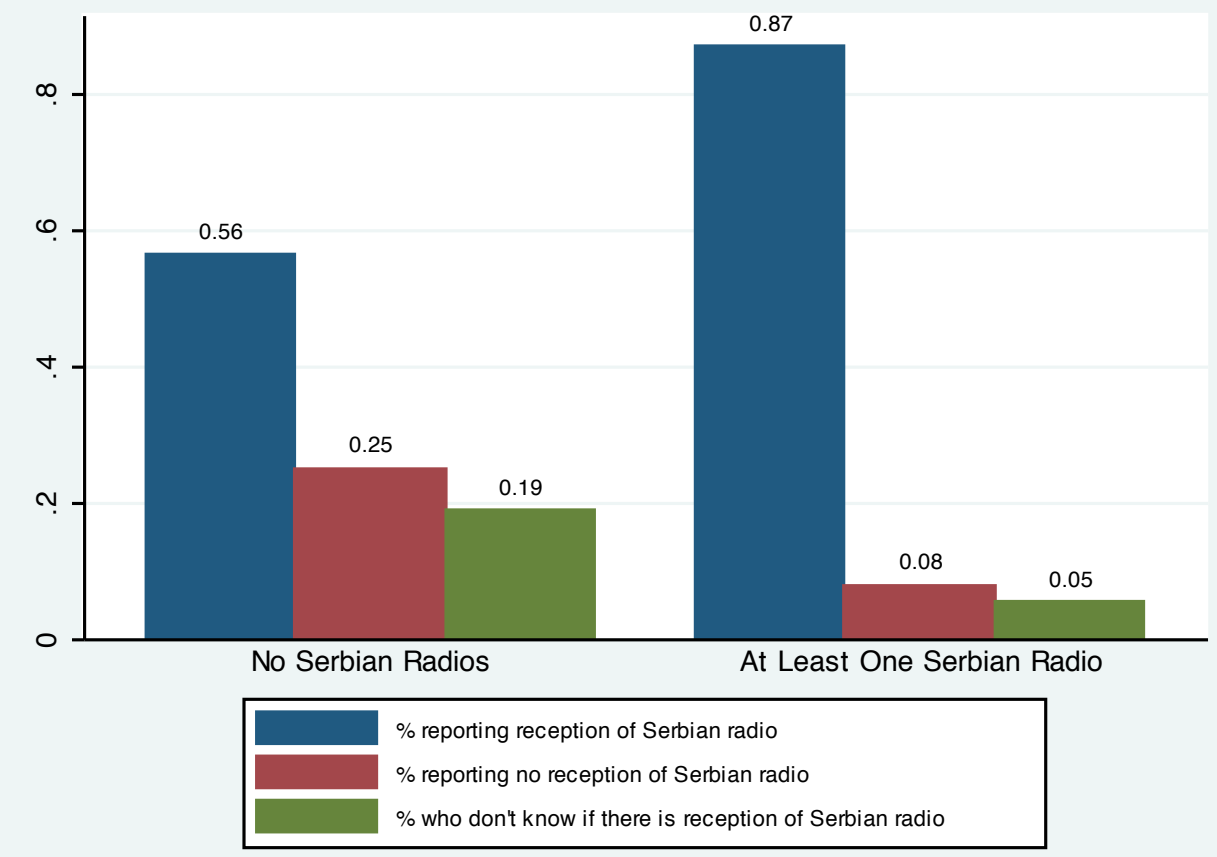

Figure 2b. Reported frequency of listening to Serbian radio (survey response), as function of availability of Serbian radio in village

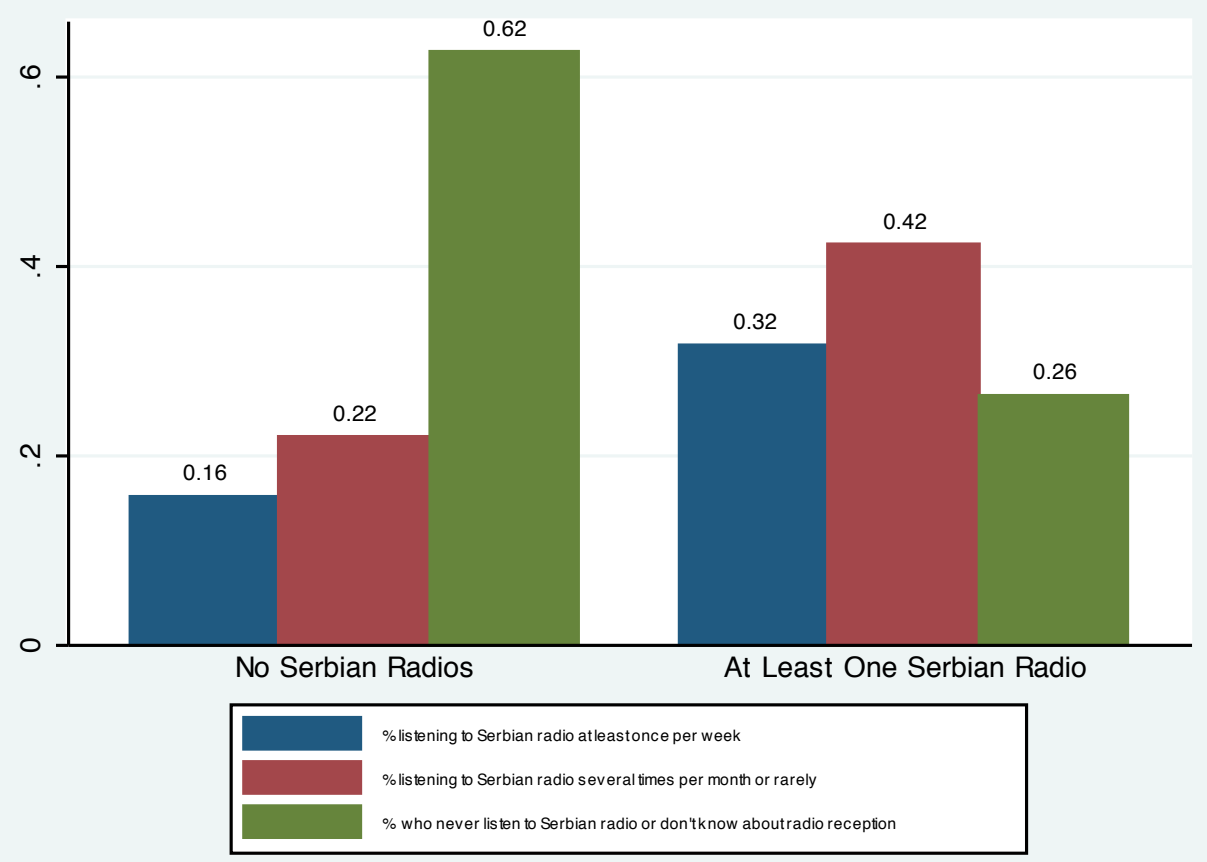

Notes: Figures $2 \mathrm{a}$ and $2 \mathrm{~b}$ tabulate the responses to two questions of an in-person survey undertaken in Dec. 2010 and Jan. 2011 in 9 of the Croatian villages in the baseline sample. We report the average responses separately for the 32 respondents in villages which we code as not having reception of Serbian radio, and for the 38 respondents in villages which we code as having reception of at least one Serbian radio. 
Figure 2c. Reported incidence of listening to Serbian radio (survey response), as function of signal strength in village.

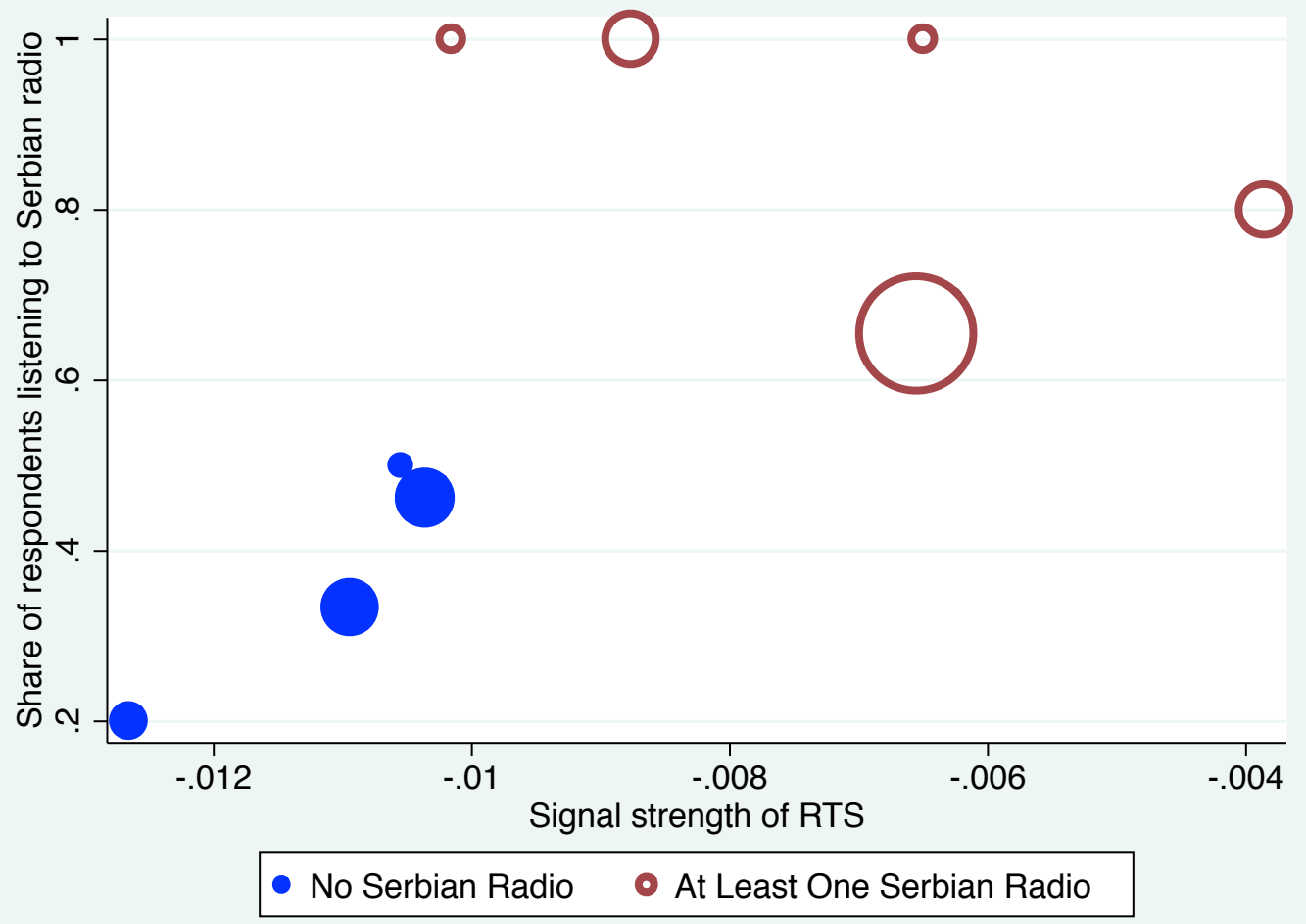

Notes: Figure 2c shows responses to a question on frequency of listening to Serbian radio in an in-person survey undertaken in Dec. 2010 and Jan. 2011 in 9 of the Croatian villages in the baseline sample. We report in solid circles the average responses for the 32 respondents in villages which we code as not having reception of Serbian radio, and with hollow circle for the 38 respondents in villages which we code as having reception of at least one Serbian radio. Size of the markers is proportional to the number of respondents in each village. 
Figure 3a. Vote share for extreme nationalistic parties in villages with, and without, reception of Serbian radio (controls).

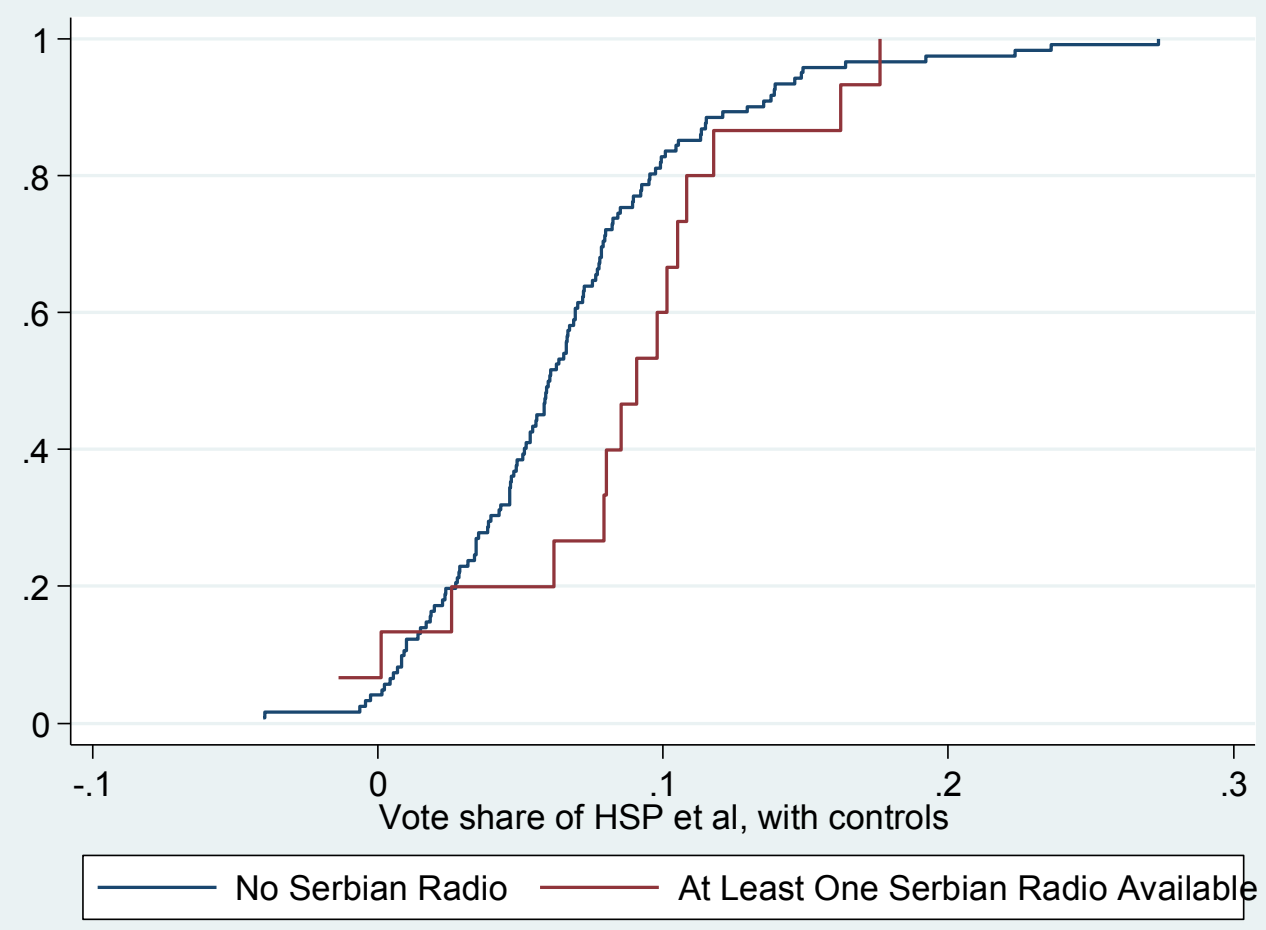

Figure 3b. Map of the vote share for extremely nationalistic parties (with controls) and the measured reception of Serbian radio.

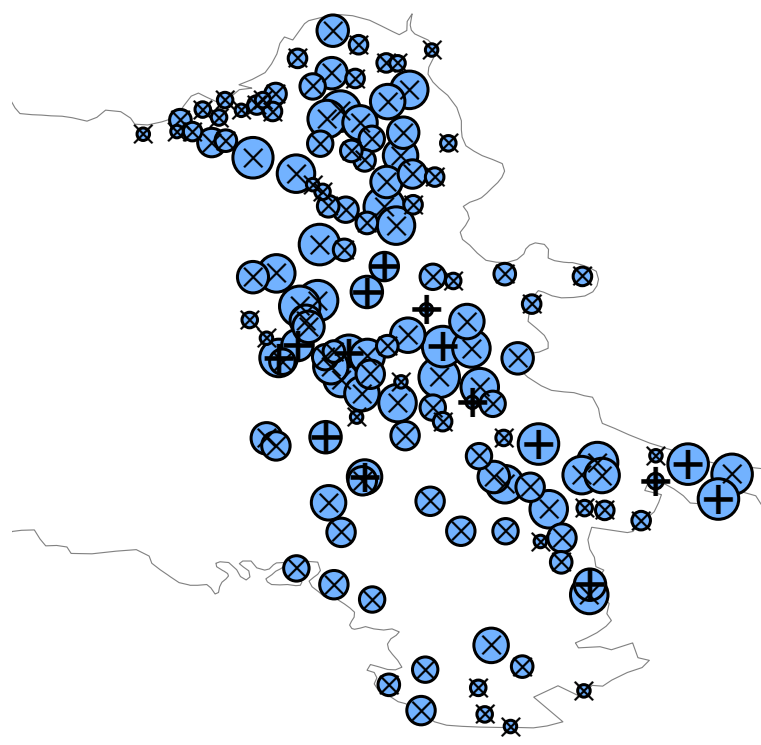
Radio availability

$$
\begin{array}{r}
\times \quad 0 \\
+\quad 1
\end{array}
$$ deciles
- $-0,106803--0,058824$
○ $-0,058823--0,041938$
O $-0,041937--0,027073$
O $-0,027072--0,013571$
O $-0,013570--0,003472$
○ $-0,003471-0,004358$
O $0,004359-0,025641$
0 $0,025642-0,042672$
0 $0,042673-0,075734$
O $0,075735-0,223518$
Croatian border

Vote for extreme nationalists 
Figure 4. Vote share of extremely nationalistic parties as function of signal strength of Serbian radio (controls, baseline sample).

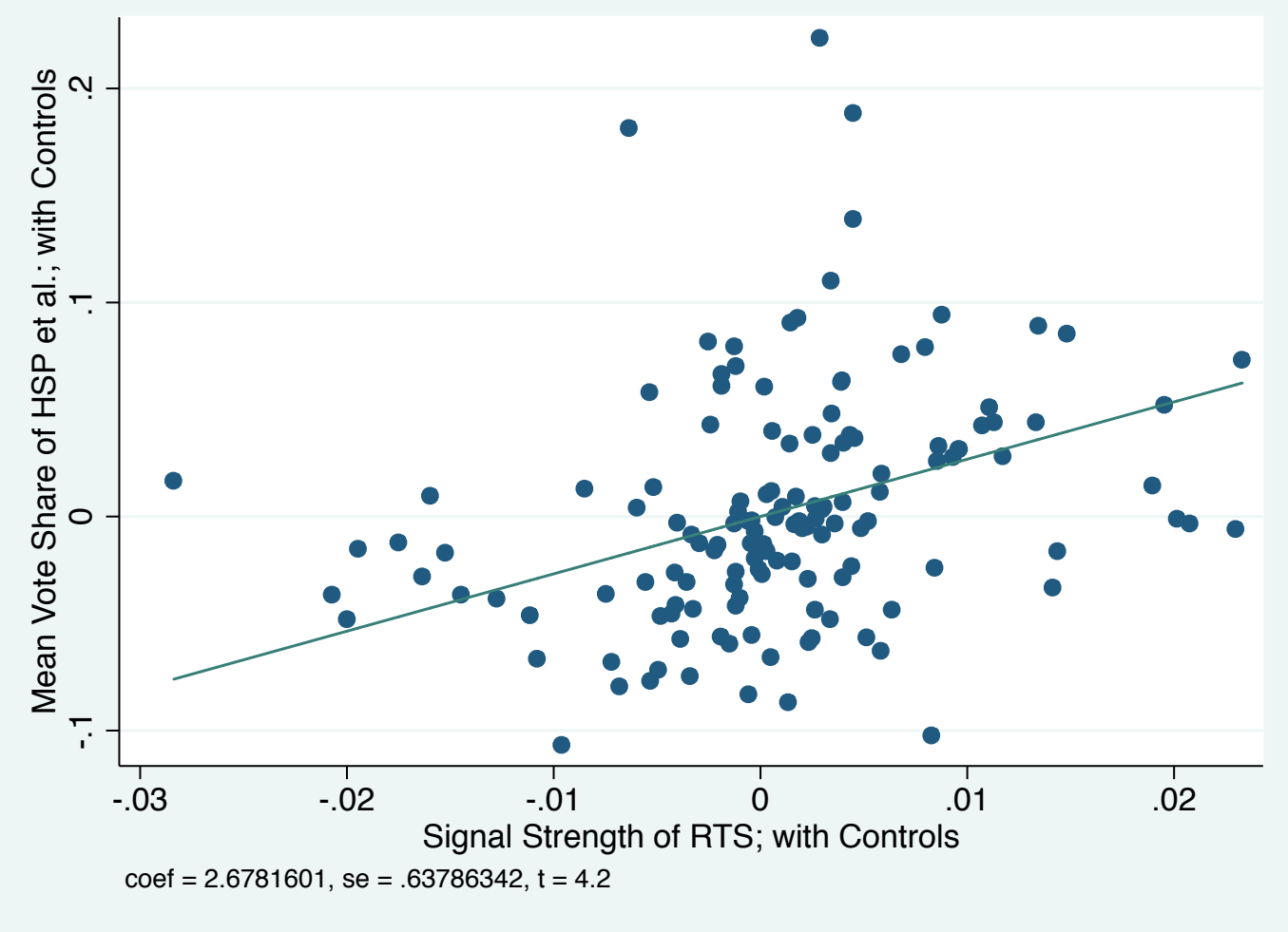

Notes: The picture shows share of votes for HSP et al. and predicted signal strength of Serbian radio after taking controls into account. Residuals are taken from the specification presented in column (3) of Table 3.

Figure 5. Example of an ethnically offensive graffiti: "Ubi Srbina" - "Kill the Serb"

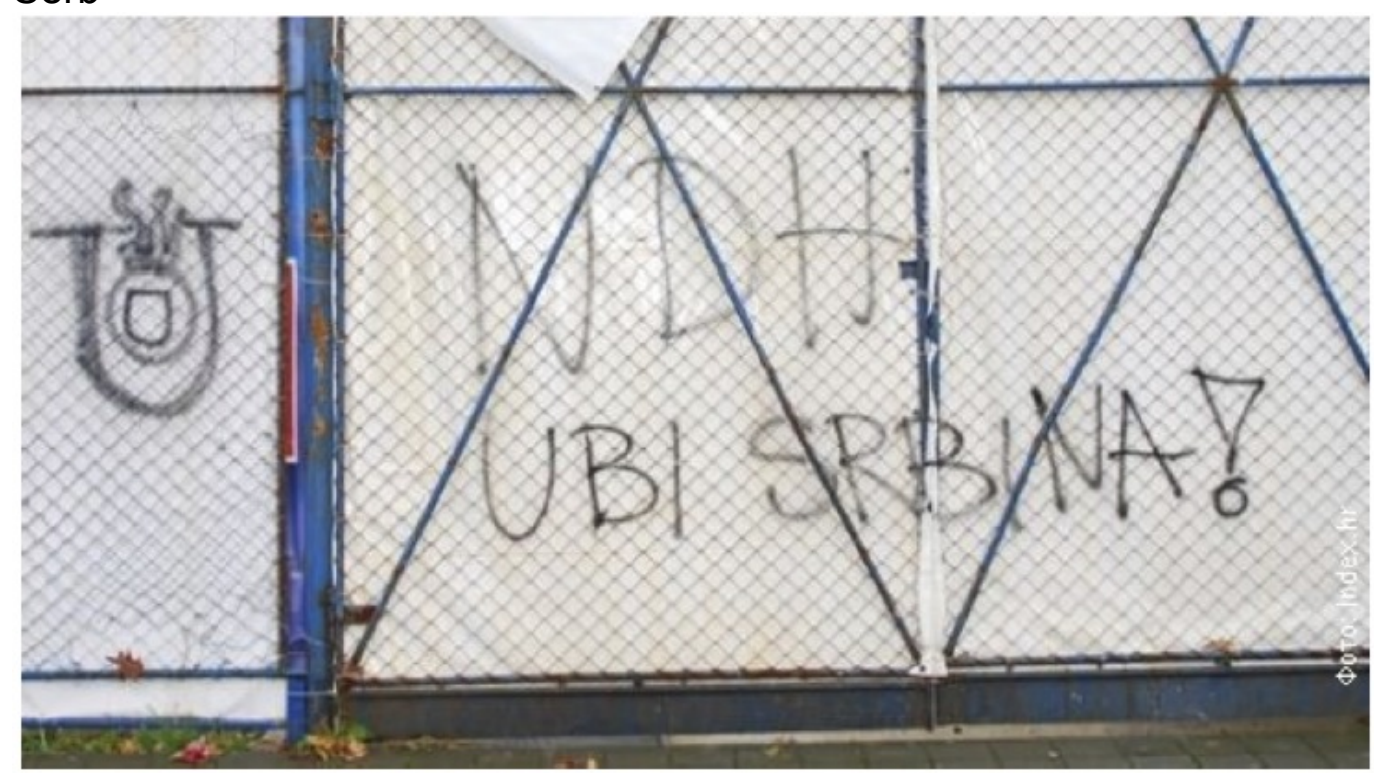


Figure 6a. Feeling thermometer toward people of different ethnic groups (Laboratory Experiment)

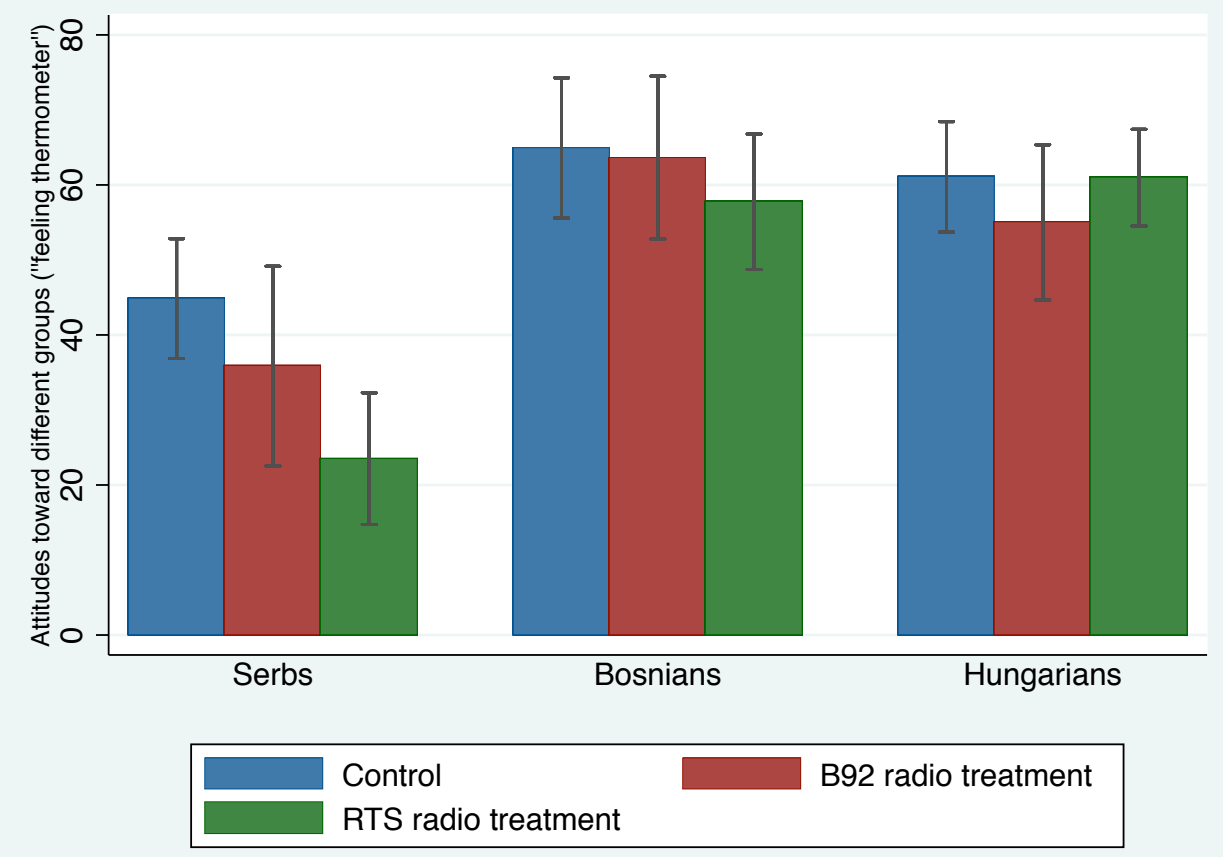

Notes: Difference between control and RTS treatment for feeling towards Serbs is significant at $1 \%$ level. All other differences are not significant.

Figure 6b. Disagreeing to work with people from different ethnic groups (Laboratory Experiment)

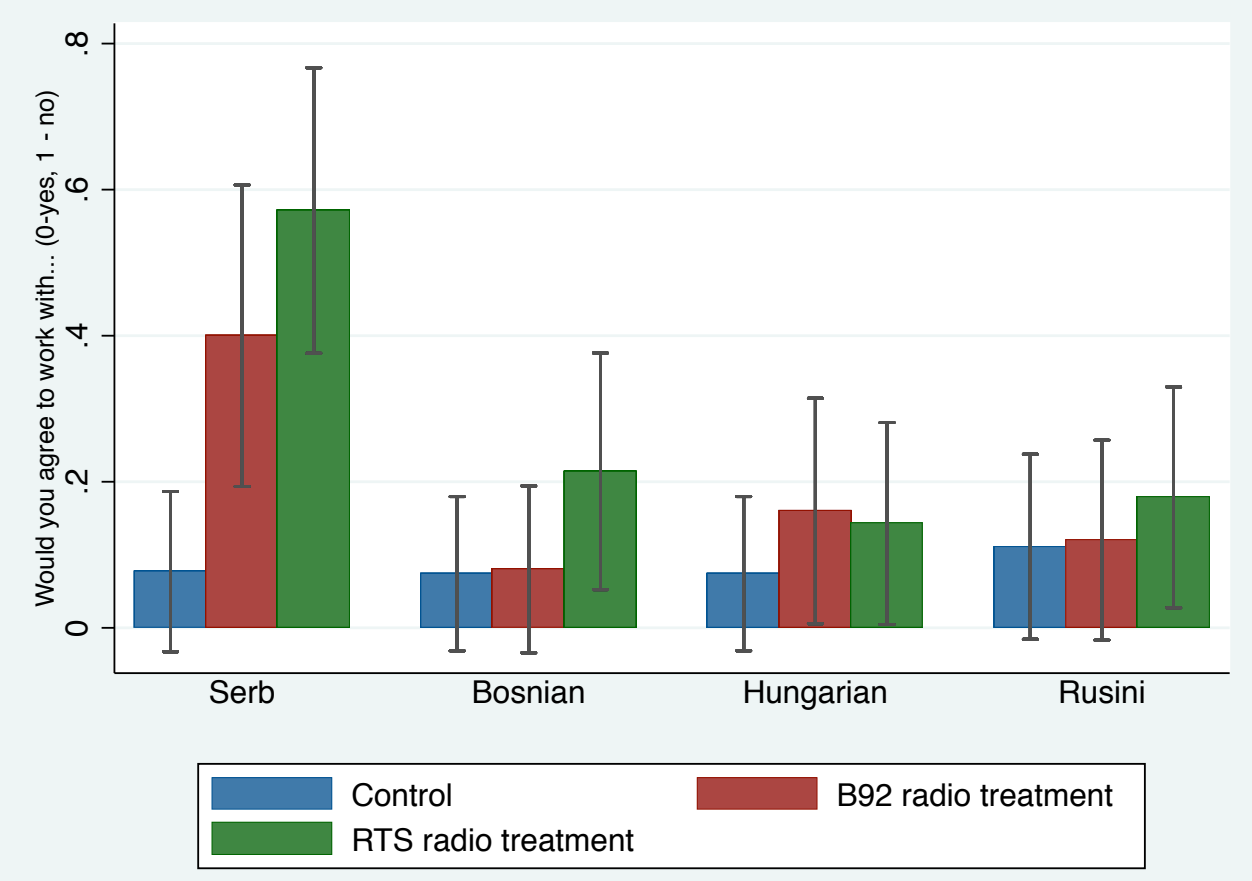

Notes: Differences between control and both treatments for Serbs are significant at 1\% level. For all the other ethnic groups, the difference is not significant. 
Figure 6c. Average rank of parties (Laboratory Experiment)

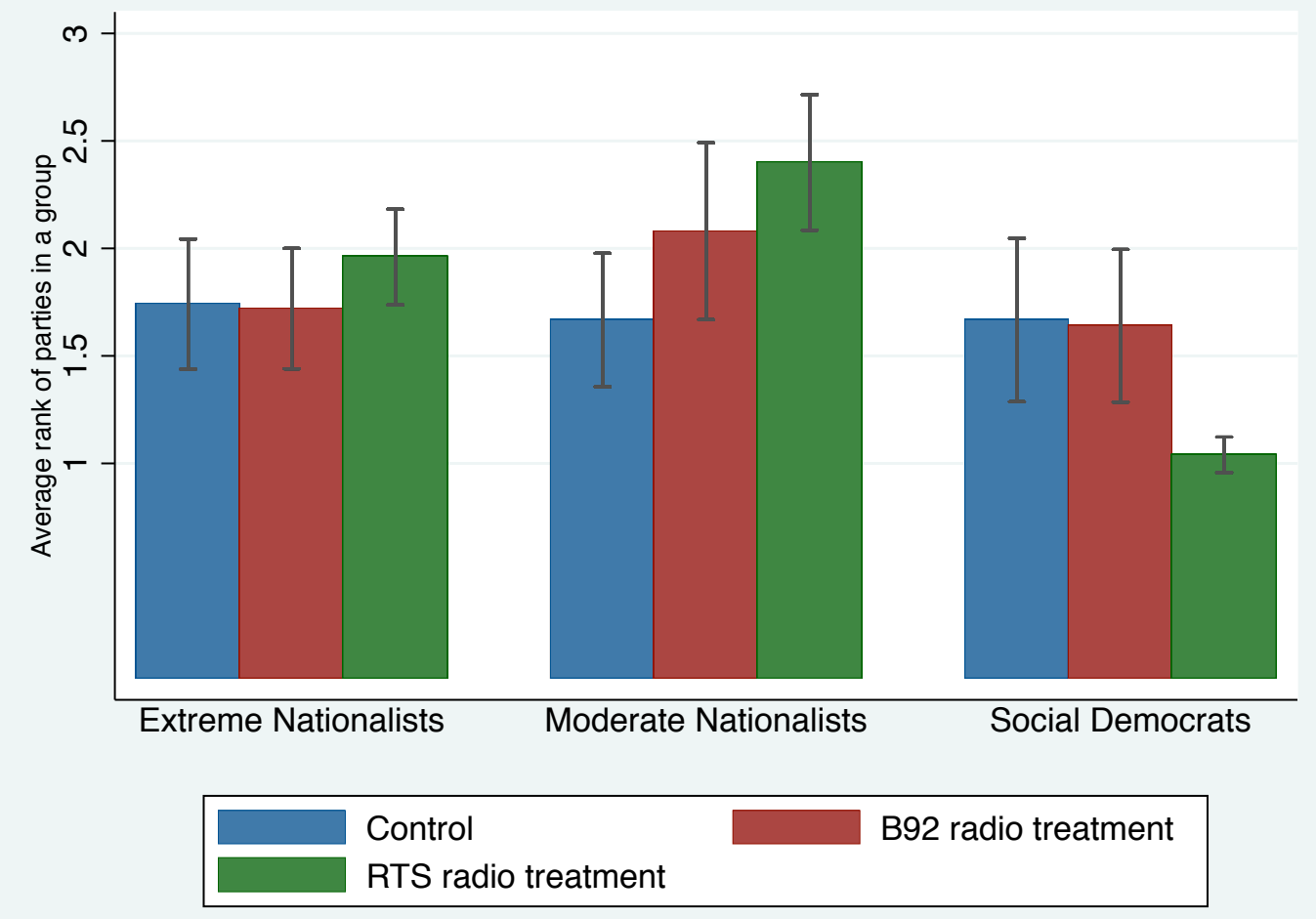

Note: Rank is coded so that a higher number denotes a greater preference towards the particular party, with rank going from 1 (lowest) to 3 (highest). The difference between control and RTS treatment for moderate nationalists is significant at $5 \%$ level. The difference between control and RTS treatment for social Democrats is significant at 1\% level. 
Table 1. Effect of Serbian radio availability on radio listenership: Survey Evidence

\begin{tabular}{|c|c|c|c|c|}
\hline \multirow{3}{*}{$\begin{array}{l}\text { Panel A. Listening at all } \\
\text { At least } 1 \text { Serbian radio available }\end{array}$} & \multicolumn{4}{|c|}{ Indicator for Survey Respondent Who Reports Listening to Serbian Radio At Least Sometimes } \\
\hline & $(1)$ & $(2)$ & $(3)$ & $(4)$ \\
\hline & $\begin{array}{l}0.362^{\star \star \star} \\
{[0.089]}\end{array}$ & $\begin{array}{l}0.313^{*} \\
{[0.139]}\end{array}$ & & \\
\hline Signal strength of Serbian Radio & & & $\begin{array}{c}55.206^{* * *} \\
{[9.767]}\end{array}$ & $\begin{array}{l}51.325^{\star *} \\
{[19.520]}\end{array}$ \\
\hline Constant & $\begin{array}{c}0.375^{* * *} \\
{[0.051]}\end{array}$ & $\begin{array}{c}0.405 \\
{[0.412]}\end{array}$ & $\begin{array}{l}1.098^{* *} \\
{[0.449]}\end{array}$ & $\begin{array}{l}1.098^{* *} \\
{[0.449]}\end{array}$ \\
\hline Controls & No & Yes & No & Yes \\
\hline Observations & 70 & 70 & 70 & 70 \\
\hline R-squared & 0.13 & 0.45 & 0.11 & 0.42 \\
\hline Effect of 1 st. dev. change & & & 0.14 & 0.13 \\
\hline & Indicator & spondent & Listening $t$ & adio Often \\
\hline Panel B. Listening often & $(1)$ & $(2)$ & $(3)$ & $(4)$ \\
\hline At least 1 Serbian radio available & $\begin{array}{c}0.16 \\
{[0.110]}\end{array}$ & $\begin{array}{c}0.144 \\
{[0.111]}\end{array}$ & & \\
\hline Signal strength of Serbian Radio & & & $\begin{array}{c}26.564 \\
{[20.450]}\end{array}$ & $\begin{array}{c}27.588 \\
{[18.373]}\end{array}$ \\
\hline Constant & $\begin{array}{l}0.156^{*} \\
{[0.077]}\end{array}$ & $\begin{array}{l}-0.266 \\
{[0.260]}\end{array}$ & $\begin{array}{c}0.076 \\
{[0.216]}\end{array}$ & $\begin{array}{c}0.076 \\
{[0.216]}\end{array}$ \\
\hline Controls & No & Yes & No & Yes \\
\hline Observations & 70 & 70 & 70 & 70 \\
\hline R-squared & 0.03 & 0.28 & 0.06 & 0.27 \\
\hline Effect of 1 st. dev. change & & & 0.07 & 0.07 \\
\hline
\end{tabular}

Notes: Data from a survey of 70 individuals in 9 villages. Respondents are asked how often, if at all, they listen to Serbian radio. They are considered to listen to Serbian radio often if they listen to it at least several times per week. Control variables include age, gender, occupation, education, and whether village was surveyed in 2011.

Robust standard errors adjusted for clusters by villages in brackets * significant at $10 \%$; ${ }^{* *}$ significant at $5 \%$; ${ }^{* * *}$ significant at $1 \%$ 
Table 2. Determinants of the availability of Serbian radio and Altonji-Elder-Taber test

\begin{tabular}{|c|c|c|c|c|}
\hline \multicolumn{5}{|c|}{ Panel A. Determinants of Serbian radio availability } \\
\hline \multirow[t]{2}{*}{ Dep. Var. in OLS Regression } & \multicolumn{2}{|c|}{$\begin{array}{l}\text { Indicator for measured Availability } \\
\text { of at least } 1 \text { Serbian (RTS) radio }\end{array}$} & \multicolumn{2}{|c|}{$\begin{array}{l}\text { Signal Strength for Serbian } \\
\text { (RTS) radio }\end{array}$} \\
\hline & $(1)$ & $(2)$ & $(3)$ & (4) \\
\hline \multirow{2}{*}{ Signal strength of all Serbian RTS radios } & & $9.183^{\star *}$ & & \\
\hline & & {$[3.637]$} & & \\
\hline \multirow[t]{2}{*}{ Distance to Serbia, logged } & -0.056 & -0.021 & $-0.0038^{* * *}$ & $-0.004^{\star * *}$ \\
\hline & {$[0.034]$} & {$[0.032]$} & {$[0.001]$} & {$[0.001]$} \\
\hline \multirow[t]{2}{*}{ Population (logged) } & -0.026 & -0.034 & 0.0009 & $0.001^{* *}$ \\
\hline & {$[0.026]$} & {$[0.029]$} & {$[0.001]$} & {$[0.001]$} \\
\hline \multirow[t]{2}{*}{$\%$ of male population } & -1.312 & -1.585 & 0.0298 & -0.011 \\
\hline & [1.084] & [1.142] & {$[0.023]$} & {$[0.012]$} \\
\hline \multirow[t]{2}{*}{$\%$ of aged $21-40$} & -2.187 & -2.273 & 0.0094 & 0.001 \\
\hline & [1.732] & [1.936] & {$[0.061]$} & {$[0.016]$} \\
\hline \multirow[t]{2}{*}{$\%$ of aged $41-60$} & -1.551 & -0.916 & $-0.0692^{\star *}$ & $-0.041^{* * *}$ \\
\hline & [1.118] & [1.091] & {$[0.031]$} & [0.013] \\
\hline \multirow[t]{2}{*}{$\%$ of aged $61+$} & $-1.405^{*}$ & -1.138 & -0.0291 & -0.006 \\
\hline & {$[0.835]$} & {$[0.886]$} & {$[0.027]$} & {$[0.010]$} \\
\hline \multirow{2}{*}{$\%$ of Croats } & -0.189 & -0.053 & $-0.0148^{*}$ & -0.003 \\
\hline & {$[0.219]$} & [0.184] & {$[0.008]$} & [0.005] \\
\hline \multirow[t]{2}{*}{$\%$ of people with higher education } & $4.544^{\star \star \star}$ & $3.543^{\star *}$ & $0.1091^{*}$ & -0.012 \\
\hline & [1.663] & [1.424] & {$[0.059]$} & {$[0.050]$} \\
\hline \multirow[t]{2}{*}{ Economically active population (\%) } & -0.239 & -0.209 & -0.0032 & $0.047^{* *}$ \\
\hline & [0.927] & [0.959] & {$[0.048]$} & {$[0.019]$} \\
\hline \multirow{2}{*}{$\begin{array}{l}\text { Disabled after the war of independence } \\
(\%)\end{array}$} & -0.781 & -3.714 & $0.3194^{\star * *}$ & $0.255^{\star * *}$ \\
\hline & [2.327] & [2.877] & {$[0.106]$} & {$[0.085]$} \\
\hline \multirow[t]{2}{*}{ Large forest nearby } & $-0.120^{*}$ & $-0.123^{*}$ & 0.0004 & \\
\hline & [0.069] & {$[0.065]$} & [0.002] & \\
\hline \multirow[t]{2}{*}{ Was important during the war } & 0.057 & 0.100 & -0.0047 & \\
\hline & {$[0.142]$} & {$[0.121]$} & {$[0.004]$} & \\
\hline \multirow{2}{*}{$\begin{array}{l}\text { Monument in the honor of died defendants } \\
\text { of the town }\end{array}$} & 0.077 & 0.079 & -0.0002 & \\
\hline & {$[0.075]$} & {$[0.076]$} & {$[0.002]$} & \\
\hline \multirow[t]{2}{*}{ Names of the streets in Cyrillic script } & -0.162 & -0.152 & -0.001 & \\
\hline & [0.150] & [0.134] & [0.004] & \\
\hline \multirow[t]{2}{*}{ Names of the streets in Hungarian } & 0.058 & 0.051 & 0.0007 & \\
\hline & {$[0.065]$} & {$[0.059]$} & {$[0.003]$} & \\
\hline Serbian beer in bars & -0.006 & -0.024 & 0.002 & \\
\hline & {$[0.124]$} & {$[0.120]$} & {$[0.002]$} & \\
\hline Region fixed effects & Yes & Yes & Yes & Yes \\
\hline R-squared & 0.17 & 0.21 & 0.643 & 0.636 \\
\hline $\begin{array}{l}\text { F-stat for joint significance of non- } \\
\text { geographic controls }\end{array}$ & 0.99 & 0.89 & $3.094^{\star * *}$ & $5.655^{\star \star *}$ \\
\hline F-stat for all the controls & $2.23^{* *}$ & $3.12^{* * *}$ & $13.35^{* * *}$ & $122.81^{* \star *}$ \\
\hline Sample & Baseline & Baseline & Baseline & Extended \\
\hline Observations & 139 & 139 & 139 & 417 \\
\hline Panel B. Altonji-Elder-Taber test of selec & tion on observ & & & \\
\hline Dep. Var. in OLS Regression: & & are for Extreme & $\overline{\text { nationalistic } \mathrm{pe}}$ & \\
\hline & $(1)$ & & $(2)$ & $(3)$ \\
\hline Prediction (based on all controls) of & 0.031 & & & \\
\hline availability of dummy for 1 Serbian radio & {$[0.062]$} & & & \\
\hline Prediction (based on all controls) of signal & & & -1.858 & -0.001 \\
\hline & & & {$[1.279]$} & {$[0.459]$} \\
\hline Controls & No controls & & No controls & No controls \\
\hline Sample & Baseline & & Baseline & Extended \\
\hline Observations & 139 & & 139 & 417 \\
\hline $\begin{array}{l}\text { Notes: Panel A reports the coefficient of OLS regress } \\
\text { 3) and for the extended sample (Column 4). The depe } \\
\text { in Columns 3-4. Panel B regresses the dependent var } \\
\text { reception based on all variables in Panel A. The univa } \\
\text { predictors for the media variable and the political varia } \\
\text { panel B are weighted by the number of eligible voters. } \\
\text { for correlation between villages in the same municipal }\end{array}$ & $\begin{array}{l}\text { ions of radio recept } \\
\text { endent variable is } \mathrm{m} \\
\text { riable of Table } 3 \text { (vo } \\
\text { ariate regression in } \\
\text { able, indicating the } \\
\text { In both panels, the } \\
\text { lity. }{ }^{*} \text { significant at } 1\end{array}$ & $\begin{array}{l}\text { all the control varia } \\
\text { d radio reception in } \\
\text { e for extremely nat } \\
\text { provides informat } \\
\text { al for bias in the rec } \\
\text { ard errors in bracke } \\
\text { significant at } 5 \% \text {; }\end{array}$ & $\begin{array}{l}\text { s for the baseline } \\
\text { lumns } 1-2 \text { and } r \text { r } \\
\text { alistic parties) on } \\
\text { on the correlation } \\
\text { sions in Tables } 3 \\
\text { are clustered by } m \\
\text { significant at } 1 \%\end{array}$ & $\begin{array}{l}\text { mple (Columns } 1 \\
\text { signal strength } \\
\text { predicted radio } \\
\text { tween the } \\
\text { oservations in } \\
\text { icipality, allowing }\end{array}$ \\
\hline
\end{tabular}


Table 3. Serbian radio and vote for extreme nationalists. Baseline sample.

\begin{tabular}{|c|c|c|c|c|c|c|c|}
\hline \multirow[t]{2}{*}{ Dep. Var. in OLS regression: } & \multicolumn{7}{|c|}{ Vote share for extremely nationalistic parties } \\
\hline & $(1)$ & $(2)$ & $(3)$ & $(4)$ & $(5)$ & $(6)$ & $(7)$ \\
\hline At least 1 Serbian (RTS) & 0.027 & $0.025^{* * *}$ & $0.026^{* * *}$ & $0.018^{*}$ & & & \\
\hline & [0.023] & {$[0.008]$} & {$[0.008]$} & [0.009] & & & \\
\hline $\begin{array}{l}\text { At least } 2 \text { Serbian (RTS) } \\
\text { radios available }\end{array}$ & & & & $\begin{array}{c}0.025 \\
{[0.019]}\end{array}$ & & & \\
\hline $\begin{array}{l}\text { Signal Strength of Serbian } \\
\text { (RTS) radio }\end{array}$ & & & & & $\begin{array}{l}-0.337 \\
{[0.786]}\end{array}$ & $\begin{array}{l}2.464^{* * *} \\
{[0.622]}\end{array}$ & $\begin{array}{l}2.678^{* * *} \\
{[0.617]}\end{array}$ \\
\hline Distance to Serbia, logged & & $\begin{array}{l}-0.015^{*} \\
{[0.008]}\end{array}$ & $\begin{array}{l}-0.016 \\
{[0.010]}\end{array}$ & $\begin{array}{l}-0.014 \\
{[0.010]}\end{array}$ & & $\begin{array}{l}-0.006 \\
{[0.007]}\end{array}$ & $\begin{array}{l}-0.006 \\
{[0.008]}\end{array}$ \\
\hline Region fixed effects & No & Yes & Yes & Yes & No & Yes & Yes \\
\hline Census controls & No & Yes & Yes & Yes & No & Yes & Yes \\
\hline Additional controls & No & No & Yes & Yes & No & No & Yes \\
\hline Mean of Dependent Variable & 0.070 & 0.070 & 0.070 & 0.070 & 0.070 & 0.070 & 0.070 \\
\hline R-squared & 0.02 & 0.60 & 0.60 & 0.60 & 0.00 & 0.63 & 0.64 \\
\hline Observations & 139 & 139 & 139 & 139 & 139 & 139 & 139 \\
\hline Implied Persuasion Rates & 0.05 & 0.05 & 0.05 & 0.03 & -0.004 & 0.03 & 0.03 \\
\hline Implied ATT & 0.09 & 0.08 & 0.08 & 0.06 & -0.01 & 0.05 & 0.05 \\
\hline
\end{tabular}

Notes: The specification report the results of OLS specifications, with the observations weighed by the number of eligible voters. This baseline sample includes

villages directly visited by the authors in 2009 and 2010 to measure the radio availability in the main street. Columns (1)-(4) use the measure of reception of RTS Serbian radio recorded on an in-person visit, while columns (5)-(7) use the signal strength computed using the transmitter location. The full set of control variables is listed in Table 2. Persuasion rates (DellaVigna and Kaplan, 2007) are computed according to the formula in the text. Implied Average Treatment on Treated effect

(ATT) is computed as the ratio of the coefficient for the effect of radio on vote to the coefficient of the effect of radio on listenership from Table 1. The standard errors in brackets are clustered by municipality, allowing for correlation between villages in the same municipality. ${ }^{*}$ significant at $10 \%$; ${ }^{* *}$ significant at $5 \%$; ${ }^{* * *}$ significant at $1 \%$ 
Table 4. Serbian radio and vote for extreme nationalists, Robustness Checks. Baseline sample.

\begin{tabular}{|c|c|c|c|c|c|c|c|c|c|}
\hline \multirow{4}{*}{$\begin{array}{l}\text { Dep. Var.: } \\
\text { Specification }\end{array}$} & \multicolumn{9}{|c|}{ Vote share for extremely nationalistic parties } \\
\hline & \multirow{2}{*}{\multicolumn{2}{|c|}{$\begin{array}{l}\text { OLS OLS } \\
\text { Control for exposure to } \\
\text { Hungarian radio }\end{array}$}} & \multirow{2}{*}{\multicolumn{2}{|c|}{$\begin{array}{c}\text { OLS OLS } \\
\text { Control for exposure to } \\
\text { Croatian radio }\end{array}$}} & \multirow{2}{*}{\multicolumn{2}{|c|}{$\begin{array}{l}\text { OLS OLS } \\
\text { Standard errors } \\
\text { corrected for spatial } \\
\text { autocorrelation }\end{array}$}} & \multirow{2}{*}{\multicolumn{2}{|c|}{$\begin{array}{l}\text { OLS OLS } \\
\text { Additional controls for } \\
\text { distance to Serbia }\end{array}$}} & \multirow{3}{*}{$\begin{array}{l}\text { Nearest-neighbor } \\
\text { matching estimate } \\
\text { (9) }\end{array}$} \\
\hline & & & & & & & & & \\
\hline & $(1)$ & $(2)$ & $(3)$ & $(4)$ & $(5)$ & $(6)$ & $(7)$ & $(8)$ & \\
\hline \multirow[t]{2}{*}{ At least 1 Serbian (RTS) radio available } & $0.026^{* *}$ & & $0.030^{* * *}$ & & $0.026^{* * *}$ & & $0.027^{* * *}$ & & $0.030^{*}$ \\
\hline & [0.010] & & [0.010] & & [0.008] & & {$[0.010]$} & & [0.016] \\
\hline \multirow{2}{*}{ Signal Strength of Serbian (RTS) radio } & & $2.699^{* * *}$ & & $2.446^{* * *}$ & & $2.678^{* * *}$ & & $2.839^{* * *}$ & \\
\hline & & [0.602] & & [0.675] & & [0.382] & & [0.753] & \\
\hline At least 1 Hungarian radio available & $\begin{array}{c}0.001 \\
{[0.023]}\end{array}$ & & & & & & & & \\
\hline \multirow{2}{*}{ Signal Strength of Hungarian radio } & & 0.223 & & & & & & & \\
\hline & & [0.941] & & & & & & & \\
\hline \multirow{2}{*}{ Signal Strength of Croatian Catholic radio } & & & 0.16 & 0.216 & & & & & \\
\hline & & & {$[0.742]$} & {$[0.751]$} & & & & & \\
\hline \multirow{2}{*}{ Signal Strength of Croatian HR radios } & & & $-1.221^{* * *}$ & $-0.810^{* *}$ & & & & & \\
\hline & & & {$[0.341]$} & {$[0.321]$} & & & & & \\
\hline \multirow[t]{2}{*}{ Travel time to Serbia } & & & & & & & 0.001 & 0.001 & \\
\hline & & & & & & & {$[0.001]$} & {$[0.001]$} & \\
\hline \multirow[t]{2}{*}{ Number of War Events within $3 \mathrm{~km}$} & & & & & & & 0.001 & 0.002 & \\
\hline & & & & & & & {$[0.007]$} & {$[0.006]$} & \\
\hline \multirow{3}{*}{$\begin{array}{l}\text { Fifth polynomial of distance to Serbia } \\
\text { Standard errors corrected for spatial } \\
\text { autocorrelation } \\
\text { Observations }\end{array}$} & No & No & No & No & No & No & Yes & Yes & No \\
\hline & No & No & No & No & Yes & Yes & No & No & No \\
\hline & 139 & 139 & 139 & 139 & 139 & 139 & 139 & 139 & 139 \\
\hline R-squared & 0.60 & 0.64 & 0.63 & 0.65 & 0.60 & 0.64 & 0.61 & 0.65 & \\
\hline Implied Persuasion Rates & 0.05 & 0.03 & 0.06 & 0.03 & 0.05 & 0.03 & 0.05 & 0.03 & 0.06 \\
\hline Implied ATT & 0.08 & 0.05 & 0.10 & 0.05 & 0.08 & 0.05 & 0.09 & 0.06 & 0.10 \\
\hline
\end{tabular}

Notes: The specification report the results of OLS with the observations weighed by the number of eligible voters. This baseline sample includes villages directly visited by the authors in 2009 and 2010 to

measure the radio availability in the main street. All specifications control for the full set of control variables listed in Table 2 . Result in column 9 reports the estimates of average treatment effect on the treated (ATT) for a nearest-neighbor matching procedure using the same set of covariates as in OLS regressions an selecting the 5 closest matching villages in the control group. The standard errors in brackets for OLS regressions are clustered by municipality, allowing for correlation between villages in the same municipality. ${ }^{*}$ significant at $10 \%$; ${ }^{* *}$ significant at $5 \%$; ${ }^{* * *}$ significant at $1 \%$ 
Table 5. Serbian radio, vote for other parties and turnout. Baseline sample.

\begin{tabular}{|c|c|c|c|c|c|c|c|c|}
\hline \multirow[t]{2}{*}{ Dep. Var. in OLS regression: } & \multicolumn{2}{|c|}{$\begin{array}{c}\text { Vote Share of } \\
\text { Extreme Nationalists }\end{array}$} & \multicolumn{2}{|c|}{$\begin{array}{c}\text { Vote Share of } \\
\text { Moderate Nationalists }\end{array}$} & \multicolumn{2}{|c|}{$\begin{array}{c}\text { Vote Share of } \\
\text { Social-Democrats }\end{array}$} & \multicolumn{2}{|c|}{ Turnout } \\
\hline & $(1)$ & $(2)$ & $(3)$ & $(4)$ & $(5)$ & $(6)$ & $(7)$ & $(8)$ \\
\hline \multirow{2}{*}{$\begin{array}{l}\text { At least } 1 \text { Serbian (RTS) } \\
\text { radio available }\end{array}$} & $0.026^{* * *}$ & & $-0.041^{*}$ & & 0.009 & & -0.009 & \\
\hline & {$[0.008]$} & & {$[0.024]$} & & {$[0.015]$} & & {$[0.017]$} & \\
\hline Signal Strength of Serbian & & $2.678^{* * *}$ & & $-4.099 * * *$ & & $1.884^{* *}$ & & -0.981 \\
\hline (RTS) radio & & {$[0.617]$} & & {$[0.838]$} & & {$[0.846]$} & & {$[1.067]$} \\
\hline Region fixed effects & Yes & Yes & Yes & Yes & Yes & Yes & Yes & Yes \\
\hline $\begin{array}{l}\text { Census and geographic } \\
\text { controls }\end{array}$ & Yes & Yes & Yes & Yes & Yes & Yes & Yes & Yes \\
\hline Manually collected controls & Yes & Yes & Yes & Yes & Yes & Yes & Yes & Yes \\
\hline Mean of Dependent Variable & 0.070 & 0.070 & 0.362 & 0.362 & 0.251 & 0.251 & 0.550 & 0.550 \\
\hline R-squared & 0.60 & 0.64 & 0.74 & 0.76 & 0.69 & 0.71 & 0.62 & 0.62 \\
\hline Observations & 139 & 139 & 139 & 139 & 139 & 139 & 139 & 139 \\
\hline Implied Persuasion rates & 0.05 & 0.03 & -0.13 & -0.06 & 0.02 & 0.02 & -0.04 & -0.02 \\
\hline Implied ATT & 0.08 & 0.05 & -0.13 & -0.08 & 0.03 & 0.04 & -0.03 & -0.02 \\
\hline
\end{tabular}


Table 6. Extended sample results (Villages within 75km of Croatian-Serbian Border).

\begin{tabular}{|c|c|c|c|c|c|c|c|c|}
\hline \multirow[t]{2}{*}{ Dep. Var. in OLS regression } & \multicolumn{2}{|c|}{$\begin{array}{l}\text { Vote share of } \\
\text { extreme nationalists }\end{array}$} & \multicolumn{2}{|c|}{$\begin{array}{l}\text { Vote share of } \\
\text { moderate nationalists }\end{array}$} & \multicolumn{2}{|c|}{$\begin{array}{l}\text { Vote share of social- } \\
\text { democrats }\end{array}$} & \multicolumn{2}{|c|}{ Turnout } \\
\hline & $(1)$ & $(2)$ & (3) & $(4)$ & $(5)$ & $(6)$ & $(7)$ & $(8)$ \\
\hline $\begin{array}{l}\text { Signal Strength of Serbian } \\
\text { (RTS) radio }\end{array}$ & $\begin{array}{c}0.394 \\
{[0.433]}\end{array}$ & $\begin{array}{l}1.552^{* *} \\
{[0.623]}\end{array}$ & $\begin{array}{c}4.127^{\star \star *} \\
{[0.919]}\end{array}$ & $\begin{array}{c}-1.934^{* *} \\
{[0.934]}\end{array}$ & $\begin{array}{l}-0.132 \\
{[0.653]}\end{array}$ & $\begin{array}{c}1.235 \\
{[0.908]}\end{array}$ & $\begin{array}{c}-1.808^{\star *} \\
{[0.729]}\end{array}$ & $\begin{array}{c}-3.080^{\star * \star} \\
{[0.767]}\end{array}$ \\
\hline Region fixed effects & No & Yes & No & Yes & No & Yes & No & Yes \\
\hline $\begin{array}{l}\text { Census and geographic } \\
\text { controls }\end{array}$ & No & Yes & No & Yes & No & Yes & No & Yes \\
\hline $\begin{array}{l}\text { Mean of Dependent } \\
\text { Variable }\end{array}$ & 0.061 & 0.061 & 0.349 & 0.349 & 0.215 & 0.215 & 0.215 & 0.215 \\
\hline R-squared & 0.007 & 0.40 & 0.15 & 0.61 & 0.000 & 0.50 & 0.07 & 0.33 \\
\hline Observations & 417 & 417 & 417 & 417 & 417 & 417 & 417 & 417 \\
\hline Implied Persuasion Rates & 0.005 & 0.02 & 0.08 & -0.03 & 0.00 & 0.02 & -0.05 & -0.05 \\
\hline Implied ATT & 0.008 & 0.03 & 0.08 & -0.04 & 0.00 & 0.02 & -0.04 & -0.06 \\
\hline
\end{tabular}

Notes: The specification report the results of OLS specifications, with the observations weighed by the number of eligible voters. This extended

sample includes villages in the broader Croatian region up to a $75 \mathrm{~km}$. distance from the Croatian-Serbian border. First two columns reproduce

columns (5) and (6) from Table 3. The full set of control variables is listed in Table 2. The standard errors in brackets are clustered by

municipality, allowing for correlation between villages in the same municipality. * significant at $10 \%$; ${ }^{* *}$ significant at $5 \%$; ${ }^{* * *}$ significant at $1 \%$ 
Table 7. Serbian radio and ethnically offensive graffiti (Probit).

\begin{tabular}{|c|c|c|c|c|c|c|c|}
\hline \multirow[t]{2}{*}{$\overline{\text { Dap. Var. in Probit Regressioı }}$} & \multicolumn{7}{|c|}{ Indicator for ethnically offensive graffiti in a village } \\
\hline & $(1)$ & $(2)$ & (3) & $(4)$ & $(5)$ & $(6)$ & (7) \\
\hline At least 1 Serbian (RTS) & $0.405^{\star \star *}$ & $0.355^{\star \star}$ & $0.361^{* *}$ & 0.311 & & & \\
\hline radio available & {$[0.101]$} & {$[0.171]$} & [0.161] & [0.245] & & & \\
\hline At least 2 Serbian (RTS) & & & & 0.076 & & & \\
\hline radios available & & & & [0.294] & & & \\
\hline $\begin{array}{l}\text { Signal Strength of Serbian } \\
\text { (RTS) radio }\end{array}$ & & & & & $\begin{array}{c}16.74^{* * *} \\
{[2.998]}\end{array}$ & $\begin{array}{l}8.558^{*} \\
{[4.589]}\end{array}$ & $\begin{array}{l}10.29^{* *} \\
{[5.109]}\end{array}$ \\
\hline Region fixed effects & No & Yes & Yes & Yes & No & Yes & Yes \\
\hline Distance to Serbia, logged & No & Yes & Yes & Yes & No & Yes & Yes \\
\hline $\begin{array}{l}\text { Census and geographic } \\
\text { controls }\end{array}$ & No & Yes & Yes & Yes & No & Yes & Yes \\
\hline Additional controls & No & No & Yes & Yes & No & No & Yes \\
\hline Mean of Dependent Variable & 0.26 & 0.26 & 0.26 & 0.26 & 0.26 & 0.26 & 0.26 \\
\hline Observations & 139 & 139 & 139 & 139 & 139 & 139 & 139 \\
\hline
\end{tabular}

Notes: All estimations use probit model. All observations are equally weighted. This baseline sample includes villages directly visited by the authors in 2009 and 2010

to measure the radio availability in the main street. The dependent variable is an indicator for the presence of a graffiti offensive towards Serbs in the village streets, as measured on an in-person visit in 2009 and 2010. The full set of control variables is listed in Table 2. Marginal effects are reported. The standard errors in brackets are clustered by municipality, allowing for correlation between villages in the same municipality. ${ }^{*}$ significant at $10 \%$; ${ }^{* *}$ significant at $5 \%$; ${ }^{* * *}$ significant at $1 \%$ 
Appendix Table A1. Summary Statistics

\begin{tabular}{|c|c|c|c|c|}
\hline & \multicolumn{2}{|c|}{ Baseline Sample } & \multicolumn{2}{|c|}{ Extended Sample } \\
\hline & Mean & Std. Dev. & Mean & Std. Dev \\
\hline \multicolumn{5}{|l|}{ Radio Availability Measures } \\
\hline At least $1 \mathrm{RTS}$ radio available & 0.11 & 0.31 & & \\
\hline At least 2 RTS radios available & 0.04 & 0.19 & & \\
\hline \multicolumn{3}{|l|}{ Dependent Variables } & -0.015 & 0.011 \\
\hline Vote share of extreme nationalistic party & 0.07 & 0.06 & 0.06 & 0.06 \\
\hline Vote share of moderate nationalistic party & 0.41 & 0.12 & 0.37 & 0.12 \\
\hline Vote share of social-democratic party & 0.24 & 0.09 & 0.24 & 0.09 \\
\hline Turnout & 0.57 & 0.08 & 0.59 & 0.08 \\
\hline Indicator for ethnically offensive graffiti & 0.42 & 0.50 & & \\
\hline \multicolumn{5}{|l|}{ Census Controls } \\
\hline Population & 8,654 & 10,999 & 6,342 & 9,122 \\
\hline$\%$ of Croats & 81.40 & 20.65 & 87.05 & 16.36 \\
\hline Disabled after the war of independence & 0.02 & 0.01 & 0.01 & 0.01 \\
\hline Economically active population & 0.41 & 0.03 & 0.40 & 0.04 \\
\hline People with higher education (\%) & 0.04 & 0.03 & 0.04 & 0.03 \\
\hline Male $(\%)$ & 0.49 & 0.01 & 0.49 & 0.02 \\
\hline People aged $21-40(\%)$ & 0.28 & 0.02 & 0.27 & 0.03 \\
\hline People of aged $41-60(\%)$ & 0.25 & 0.03 & 0.25 & 0.04 \\
\hline People of aged $61+(\%)$ & 0.20 & 0.05 & 0.21 & 0.06 \\
\hline \multicolumn{5}{|l|}{ Geographic Controls } \\
\hline Distance to Serbia $(\mathrm{km})$ & 17.65 & 8.89 & 33.64 & 20.04 \\
\hline Large forest nearby & 0.21 & 0.41 & & \\
\hline \multicolumn{5}{|l|}{ Additional Controls } \\
\hline Monument in honor of defendants of the town & 0.66 & 0.48 & & \\
\hline Names of the streets in Cyrillic script & 0.04 & 0.19 & & \\
\hline Names of the streets in Hungarian & 0.02 & 0.15 & & \\
\hline Serbian beer in bars & 0.03 & 0.18 & & \\
\hline Was important during the war & 0.21 & 0.41 & & \\
\hline Number of observations & \multicolumn{2}{|c|}{139} & \multicolumn{2}{|c|}{417} \\
\hline
\end{tabular}

Notes: List of all the control variables for the baseline sample of villages (Columns 1-2) and for the extended sample (Columns 3-4). Observations are weighted by the number of eligibe voters. 